San Jose State University

SJSU ScholarWorks

Master's Theses

Master's Theses and Graduate Research

1992

\title{
The decline of Santa Clara County's fruit and vegetable canning industry (1967-1987)
}

Roseanne Dominguez

San Jose State University

Follow this and additional works at: https://scholarworks.sjsu.edu/etd_theses

\section{Recommended Citation}

Dominguez, Roseanne, "The decline of Santa Clara County's fruit and vegetable canning industry (1967-1987)" (1992). Master's Theses. 306.

DOI: https://doi.org/10.31979/etd.jewt-553k

https://scholarworks.sjsu.edu/etd_theses/306

This Thesis is brought to you for free and open access by the Master's Theses and Graduate Research at SJSU ScholarWorks. It has been accepted for inclusion in Master's Theses by an authorized administrator of SJSU ScholarWorks. For more information, please contact scholarworks@sjsu.edu. 


\section{INFORMATION TO USERS}

This manuscript has been reproduced from the microfilm master. UMI films the text directly from the original or copy submitted. Thus, some thesis and dissertation copies are in typewriter face, while others may be from any type of computer printer.

The quality of this reproduction is dependent upon the quality of the copy submitted. Broken or indistinct print, colored or poor quality illustrations and photographs, print bleedthrough, substandard margins, and improper alignment can adversely affect reproduction.

In the unlikely event that the author did not send UMI a complete manuscript and there are missing pages, these will be noted. Also, if unauthorized copyright material had to be removed, a note will indicate the deletion.

Oversize materials (e.g., maps, drawings, charts) are reproduced by sectioning the original, beginning at the upper left-hand corner and continuing from left to right in equal sections with small overlaps. Each original is also photographed in one exposure and is included in reduced form at the back of the book.

Photographs included in the original manuscript have been reproduced xerographically in this copy. Higher quality 6" $\times 9$ " black and white photographic prints are available for any photographs or illustrations appearing in this copy for an additional charge. Contact UMI directly to order.

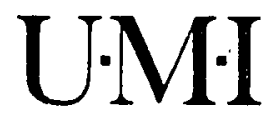

University Microfilms International 


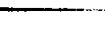


Order Number 1348667

The decline of Santa Clara County's fruit and vegetable canning industry (1967-1987)

Dominguez, RoseAnne Teresa, M.A.

San Jose State University, 1992 
$+$ 


\title{
THE DECLINE OF SANTA CLARA COUNTY'S FRUIT AND VEGETABLE CANNING INDUSTRY (1967-1987)
}

\author{
A Thesis \\ Presented to \\ The Faculty of the Department of Geography \\ San Jose State University \\ In Partial Fulfillment \\ of the Requirements for the Degree \\ Master of Arts
}

By

RoseAnne Dominguez

May 1992 
APPROVED FOR THE DEPARTMENT OF GEOGRAPHY hul Toburaura

Dr. Bill Takizawa $\bigcirc$ Faculty Member Dr. Richard Ellefsen Garksulamo Jack Perkins Food Processing Consultant

Fod Processing Consultant

APPROVED FOR THE UNIVERSITY

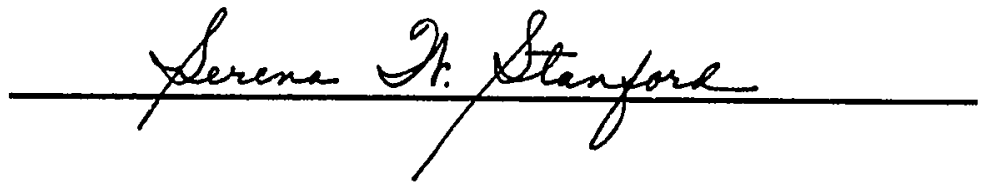




\begin{abstract}
THE DECLINE OF SANTA CLARA COUNTY'S FRUIT AND VEGETABLE CANNING INDUSTRY (1967-1987)
\end{abstract}

\begin{abstract}
by RoseAnne Dominguez
This study applies relocation theory to identify and explain the key factors that influenced the decline of the fruit and vegetable canning industry in Santa Clara County. A variety of theoretical approaches to industrial location and movement were considered, but only the behavioralist approach outlined by Townroe (1969) was selected as the theoretical perspective for this study. It stresses the decision making processes and the factors that influence industrial location.

Factors affecting the canning industry are reviewed. Analysis indicates that the canning industry is affected by some that are within as well as those which are beyond its sphere of influence. Finally an assessment of the industry's future in Santa Clara County is presented.
\end{abstract}




\section{ACKNOWLEDGEMENTS}

Many people have helped me in this research. I extend my deepest appreciation and gratitude to my committee, Mr. Jack Perkins, Dr. Bill Takizawa, and Dr. Richard Ellefsen. Mr. Jack Perkins who has been a mentor for many years, sparked my interest in the canning industry. Without his help this research would have never been undertaken. My academic advisors dramatically shaped and guided my interests within the discipline. Dr. Takizawa's willingness to listen and overall concern greatly facilitated the writing of this project. Dr. Ellefsen's non-stop enthusiasm for the discipline was addictive; he showed me the wonder and fascination of geography.

Additional thanks go to the crew at Ames, especially Honoris, Marty and Bruce. Without Honoris I would have never figured out the many facets of my computer. She helped me to overcome two hard drive failures. Marty's enthusiasm and support was tremendous. Bruce's persistent encouragement and critique of my graphic design was invaluable. His concern deserves special thanks.

The support and care of my family cannot be overlooked. There was a time when I truly felt this was an impossible task. My parents, Simon and Rosemary, helped me to realize my potential; their support never wavered. 


\section{TABLE OF CONTENTS}

Page

ABSTRACT
ACKNOWLEDGEMENTS
LIST OF FIGURES
CHAPTER

1. Introduction $\quad \ldots \ldots \ldots \ldots \ldots \ldots \ldots \ldots \ldots \ldots \ldots \ldots$

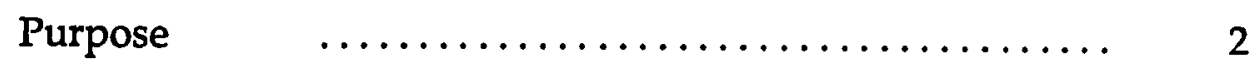

Format $\quad \ldots \ldots \ldots \ldots \ldots \ldots \ldots \ldots \ldots \ldots \ldots \ldots \ldots \ldots \ldots \ldots \ldots \ldots$

2. Literature Review $\ldots \ldots \ldots \ldots \ldots \ldots \ldots \ldots \ldots \ldots \ldots \ldots$

Economic Theory $\ldots \ldots \ldots \ldots \ldots \ldots \ldots \ldots \ldots \ldots \ldots$

Industrial Geographic Approaches $\ldots \ldots \ldots \ldots \ldots \ldots \ldots$

3. The Canning Process $\quad \ldots \ldots \ldots \ldots \ldots \ldots \ldots \ldots \ldots \ldots \ldots . \ldots \ldots$

4. Methodology $\quad \ldots \ldots \ldots \ldots \ldots \ldots \ldots \ldots \ldots \ldots \ldots \ldots \ldots \ldots \ldots \ldots \ldots$

5. Landscape Change $1930-1987 \quad \ldots \ldots \ldots \ldots \ldots \ldots \ldots \ldots \ldots \ldots \ldots \ldots$

6. Santa Clara County's Canning History .............. 42

7. Results and Analysis $\ldots \ldots \ldots \ldots \ldots \ldots \ldots \ldots \ldots \ldots \ldots$

County Agricultural Production $\ldots \ldots \ldots \ldots \ldots \ldots \ldots \ldots$

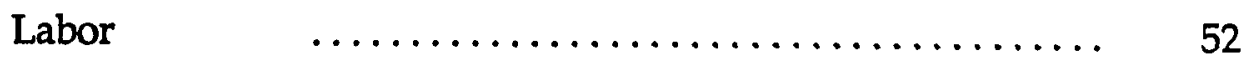

Waste Disposal and Government Policy $\ldots \ldots \ldots \ldots \ldots 6$

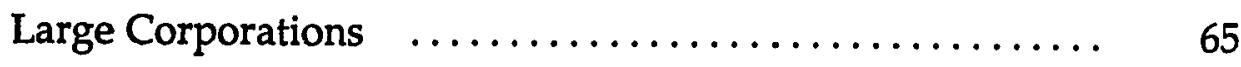

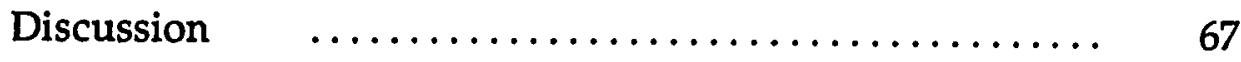

8. Conclusion $\quad \ldots \ldots \ldots \ldots \ldots \ldots \ldots \ldots \ldots \ldots \ldots \ldots \ldots \ldots \ldots$

REFERENCES $\quad \ldots \ldots \ldots \ldots \ldots \ldots \ldots \ldots \ldots \ldots \ldots \ldots \ldots \ldots \ldots \ldots \ldots$ 


\section{LIST OF FIGURES}

Figure 4.1 Pearson's Product Moment Correlation $\ldots \ldots \ldots \ldots \ldots .30$

Figure 5.1 Climograph of the Santa Clara Valley $\ldots . \ldots \ldots \ldots \ldots . \quad 32$

Figure 5.2 Santa Clara County's orchard acreage $\ldots \ldots \ldots \ldots \ldots .33$

Figure 5.3 Santa Clara County land use $1931 \ldots \ldots \ldots \ldots \ldots \ldots$

Figure 5.4 Santa Clara County's population $\ldots \ldots \ldots \ldots \ldots \ldots \ldots, 36$

Figure 5.5 Average annual employment by industry $\ldots \ldots \ldots \ldots . \quad 37$

Figure 5.6 North Santa Clara County land use $1961 \ldots \ldots \ldots \ldots . . . . .39$

Figure 5.7 North Santa Clara County land use $1986 \ldots \ldots \ldots \ldots \ldots \quad 41$

Figure 6.11920 cannery distribution $\ldots \ldots \ldots \ldots \ldots \ldots \ldots \ldots \ldots, 43$

Figure 6.2 County's fruit and vegetable processing industry $\ldots \ldots \ldots 45$

Figure 6.3 Central Santa Clara County canning production $1967 \ldots . .46$

Figure 6.4 West Santa Clara County canning production $1967 \ldots \ldots .47$

Figure 6.5 California's fruit and vegetable canning seasons ...... 48

Figure 6.61967 canned fruit and vegetable production $\ldots \ldots \ldots \ldots .60$

Figure 7.1 Trends in fruit and vegetable acreage and canneries ...... 51

Figure 7.2 Change in apple production $\ldots \ldots \ldots \ldots \ldots \ldots \ldots \ldots, 53$

Figure 7.3 Change in apricot production $\ldots \ldots \ldots \ldots \ldots \ldots \ldots . \ldots \ldots$

Figure 7.4 Change in cherry production $\ldots \ldots \ldots \ldots \ldots \ldots \ldots . . \ldots 5$

Figure 7.5 Change in peach production $\ldots \ldots \ldots \ldots \ldots \ldots \ldots \ldots . \ldots \ldots$

Figure 7.6 Change in pear production $\quad \ldots \ldots \ldots \ldots \ldots \ldots \ldots \ldots, 57$

Figure 7.7 Change in plum and prune production $\ldots \ldots \ldots \ldots \ldots .68$

Figure 7.8 Change in tomato acreage $\quad \ldots \ldots \ldots \ldots \ldots \ldots \ldots \ldots . \ldots \ldots$

Figure 7.9 Correlation coefficient for total employment and cost .... 60 
Figure 7.10 Trends in costs for sewage discharge and canneries ...... 64

Figure 7.11 U.S. civilian fruit and vegetable consumption $\ldots \ldots \ldots 66$

Figure 7.12 Santa Clara County cannery ownership $\ldots \ldots \ldots \ldots \ldots 67$

Figure 7.13 Fruit and vegetable acreage totals $\ldots \ldots \ldots \ldots \ldots \ldots 68$

Figure 7.141987 canned fruit and vegetable production $\ldots \ldots \ldots \ldots .669$ 


\section{INTRODUCTION}

Santa Clara County has experienced dramatic change and growth. At the turn of the century, agriculture formed the base of Santa Clara County's economy. A reputation for agricultural fecundity prompted the dubbing of Santa Clara Valley as the "Valley of Heart's Delight." From this agricultural base the fruit and vegetable canning industry developed; the first cannery was established in San Jose in the 1870's.

The industry flourished thanks in part to the variety of crops grown in the County. By the 1920's and 1930's California led the nation in fruit and vegetable canning and Santa Clara County led the state. Not only was the area a high volume producer, it was an industry innovator as well. New products and more efficient canning machinery were constantly being developed.

Fruit and vegetable processing remained an important industry through the 1950's and early 1960's. During the late 1960's the County's production accounted for a substantial portion of the state's total output. Since then, the industry has nearly disappeared.

Few studies regarding this area's fruit and vegetable industry have been done. Claus (1966) offers the most extensive examination of the Santa Clara Valley's canning industry. The work categorizes the County's processors as being oriented to either the market or the raw materials needed for production. Emphasis is also placed on the history and development of the industry within the Valley. Other works such as Payne (1987) and Jacobson (1984) only briefly describe the industry. 
The spatial distribution of industry has a great history within the field of geography. Initial works attempted to explain why industries chose a particular location. Recent works have used a wide variety of theoretical approaches to understand the changing patterns of industrial location.

\section{Purpose}

This study is an application of relocation theory. The emphasis is on identifying and explaining the key factors that influenced the decline of the fruit and vegetable canning industry in Santa Clara County. Although the industry is as large as ever in the state, the position in the County has fallen from one of preeminence to almost non-existence.

The process of decline covers the closing of individual canning operations and the movement of food processing facilities out of the County.

\section{Format}

The format of this work is as follows. The theoretical literature is reviewed in Chapter Two. The chapter relates the variety of theoretical approaches used to study industrial location and movement. These include the classical economic theories of Weber, Lösch, Isard, and Greenhut as well as the conceptual approaches used by industrial geographers to examine the relocation of industry. The latter includes neoclassical, behavioral, structural, and system theories.

Chapters Three through Six provide pertinent background information. Chapter Three briefly explains the process of canning both fruits and vegetables and also describes the material factors of production. Chapter Four explains the theoretical approach, methodology, and factors examined for this study. Chapter Five describes the change in the County's landscape, 
from predominantly orchard to an urban agglomeration. Chapter Six relates the growth pinnacle and decline of the industry in Santa Clara County.

The remaining chapters depict the findings and conclusions of the study. Chapter Seven details the results and discusses the research. Chapter Eight summarizes the findings, forecasts the industry's future in Santa Clara County, and relates the significance of this research. 


\section{LITERATURE REVIEW}

The literature concerning industrial location and relocation is examined here. The several theoretical approaches used to study the spatial distribution of industry will be presented in an historical format so that the development of current trends can be fully appreciated.

The study of industrial relocation, lying within the fields of industrial and economic geography, is closely tied to location theory and has undergone an extraordinary evolution. Much of the early work was concerned primarily with the initial location of industry. The first theories drew heavily from the field of economics. As a result, economics and economic principles were the methods used for studying the industrial environment.

During the post World War II years, dramatic changes in the industrial structure became evident. Industrial geographers were forced to reevaluate the way location was studied. New factors, outside economic rationality, were affecting location decisions. Because industrial movement increased dramatically, new interest was sparked in the study of industrial relocation. Established theories were subjected to dramatic critical examination.

\section{Economic Theory}

The study of industrial location was begun by economists who developed and formed location theory. The first theoretical works were completed at the turn of the century. These theories are presented to give historical depth to the development of industrial location and relocation theory. They are presented in brief overview, to establish the base from which current themes have developed. 


\section{Least Cost Theory}

The least cost theory was developed by Alfred Weber (1929) who was a German economist. He developed the first theory of industrial location. His initial work, published in German in 1909, was translated into English in 1929.

This theory assumes managers are all knowing, firms are perfectly competitive and seek to maximize profit. Location is a function of least cost, meaning the best or optimal location is one at which costs are minimized. The factors that influence the optimal location include the costs of transportation and labor. Of these, transportation costs are of prime concern.

Weber placed particular emphasis on the transport costs involved in assembling materials at the manufacturing site and in delivering the finished product to the market. The theory also recognizes the impact of labor costs and that savings may be achieved through agglomeration. These factors are explained using the concept of the critical isodapane. This concept is a line or contour of equal transport cost. If labor costs differ within the isodapane, the firm will move to the point where labor savings can be realized.

Weber's theory has one basic limitation. It did not account for the potential effect of a competitor's location. In effect, demand was held constant. It assumed that manufacturers can sell everything they produce. Greatest Profit or Market Area Theory

The market theory was developed by August Lösch (1954), another German economist who sought a general theory of rational location. This theory asserts that the market will be supplied with new firms, and the density of these plants will increase until equilibrium is reached (Watts, 1987). 
His work, originally written in German in 1940, was translated into English in 1954. This is the first general theory using demand as the major spatial variable.

Lösch asserts that only when factors of production are exhaustible, immobile or unique are they of great importance. Consequently, the focus is on the market area and the way markets are shared. Producers seek a location where they can control the largest possible market area. In effect, manufacturers attempt to exercise monopolistic control over their area. Control is achieved by providing the product at the lowest price. The price charged to consumers is based on the cost of overcoming the distance to the factory. Thus, transportation and distance to the market are major concerns.

Location is a function of both cost and demand and therefore the optimal location may favor a point where neither production nor transport costs are lowest. The market area theory is similar to Weber's in that transportation and labor costs are stressed. However, optimal location is defined by greatest nominal profit, not simply least cost.

Equilibrium is characterized by five conditions. The first is that each location must be as advantageous as possible. The second is there must be numerous competitors. The third and fourth are closely tied together. The increase in the number of competitors reduces the size of each market until the boundaries between each are delimited by lines of indifference. When this occurs the fifth condition is met, all abnormal profits disappear.

The market area theory has two weaknesses in explaining industrial location. The first is that it disregards spatial cost variations. The costs of production factors are not fixed but vary from location to location. The second 
is that its focus is the market and this focus makes the theory most applicable to the retail sector of the economy.

\section{Walter Isard}

The objective of Isard's Location and Space Economy was to develop principles for a general theory of location. He draws heavily from the works of others.

Isard (1956) applies the economic principle of substitution to explain location. The substitution principle explains how replacement of one resource for another achieves optimal results. It examines land, labor, capital, and transport costs. In a broad application, firms examine the extent to which labor can be substituted for land or capital or vice versa. The optimal location is defined as the site where nothing can be gained by substituting one factor for another.

Isard builds his rationale for location, primarily on the work done by Weber. He generalizes Weber's theory to incorporate market and supply areas. He also incorporates Löschian market concepts into his general theory. As did Lösch, Isard developed a general theory of location. His focus, however, is on manufacturing. The end result is applicable to all aspects of the space economy (Smith, 1971).

\section{Melvin Greenhut}

Melvin Greenhut is an American economist. His goal was to derive a more ambitious theoretical representation of location. This theory of location attempts to incorporate all types of location factors .

Greenhut (1956) identifies three categories for location factors. These are demand, cost and 'purely personnel' considerations (Chapman \& Walker, 
1987). Demand factors are the variables that influence demand. Examples include, the locations of buyers and competitors as well as the nature of demand for the product. Cost factors are divided into three groups. The first incorporates the cost of running the factory itself. These include the cost of land, taxes, capital, insurance, and fuel. The second is the cost of labor. This is not limited simply to wage. It is influenced by factors that impact the health and well being of personnel; these include the community, park, and education facilities. The last cost category includes the cost of materials and transportation. Greenhut realized that many factors influencing location couldn't be grouped as either cost or demand. These he placed in a special category, 'purely personnel'. These factors address the fact that manufacturers receive benefits that are not financial (Chapman \& Walker 1987). These include environmental preferences, security, and psychic income. The latter refers to the size of the plant.

Greenhut's theory, like the other economic theories, considers only the initial locational choice for a given firm. Movement or relocation isn't considered, nor is the impact of a changing economic structure. The overall emphasis of economists has been to integrate location theory into mainstream economics.

\section{Industrial Geographic Approaches}

Industrial geographers, while using and incorporating the findings of their economic predecessors in their works, have been more concerned with the dynamism of industrial location, the relocation of specific firms and the altered distribution of an entire industry. The research in this category 
follows four major themes: neoclassicism, behavioralism, Marxist structuralism, and the system approach.

Each of the four has developed and changed. The neoclassical and behavioral approaches are well established and account for the majority of the research done in the field. The Marxist and system approach have only recently been used to explain movement. The focus of this section will be to explain the underlying assumptions of each approach as well as describe the reasons for their development. Examples of each approach will also be discussed.

Neoclassical Approach

The work of neoclassical researchers evolved directly from the work done by economists. In fact, the initial location theories were derived using neoclassical economic principles. The impact of this is that this body of work is underscored by two basic assumptions. The first stipulates decisions are made with perfect knowledge and man is perfectly rational. "Economic man" is the term used to describe the latter (Walker, 1975). The second is that firms locate where profits are the greatest. Given these two assumptions, locational shift is explained as the:

direct response to spatial shifts in the prices of production factors such as labour or land or to a spatial shift in revenue (Lever, 1985, pp. 11-12).

Relocation is explained as an adjustment to the changing costs of production.

The factors used to explain relocation are the costs of transportation, land, and labor. Transportation is directly related to distance. The costs involved include transporting raw materials to the firm and moving the 
finished product to market. Transportation in and of itself is seldom the dominant factor for industrial migration.

Land prices vary sharply, especially at the intraurban level. At this level, the price of land is closely related to space constraints. Alonso (1967) expands on classical location theory by introducing this land dynamic as a factor for the migration of industry from the city. He establishes an optimal firm location based on distance from the city center. Rent gradients within the city are established to represent the variation in the cost of land. Alonso asserts that the price of land is the primary motivation for relocation. He supports this by demonstrating that at the intraurban level, transport costs vary slightly, thus land costs attain greater significance. The insignificance of transport costs, at the intraurban level, is supported by Scott (1982). If the rent differential offers adequate savings, firms will abandon the city center.

Labor's influence on relocation is somewhat ambiguous. The difficulty is that not all regions exhibit differential wage rates. If labor is to be incorporated as a factor influencing location, a method for measuring labor differences needs to be addressed. In countries where wages are set by national agreement hourly wage rates are ignored. In these areas, the efficiency wage is examined. This defines labor cost per unit of output (Lever, 1985). It is difficult to measure and in these areas labor cost is considered less important. Labor costs, however, are significant in countries with variable labor pool costs. Foster (1972) emphasizes wage differentials to explain the movement of industry into the southeastern portion of the United States. 


\section{Behavioral Approach}

The focus of the behavioral approach is the decision making process. Special attention is also placed on the impact of large corporations. This approach developed as a reaction to the shortcomings of neoclassical theories.

Researchers were dissatisfied with established neoclassical theory. The reasons for their dissatisfaction are outlined by Lever (1985). Empirical studies were demonstrating how little information was being used to make locational choices. In addition, it was becoming apparent that the information used was often inadequate or incorrect. This destroyed the underlying assumption of economic rationality. Another important event was the formation of large corporations. These companies could influence the cost of labor as well as land. This reduced the importance of these factors. The third area of interest was related to policy. It became increasingly obvious that there was a need to incorporate the effects of large scale government policy into location theory. These major events have shaped the current interest of industrial geographers.

Behavioral theories call specific attention to two of the shortcomings of neoclassical theory. The first is that decision makers do not have perfect information. Decisions are made only with the available information. In many cases the amount of information used is minimal and incorrect. The second relates to the idea of an optimal location.

Behavioral theory goes beyond the assumption of profit maximization. It demonstrates that it is possible and desirable to make a conscious choice for a location where profits are not maximized. Behavioral theory offers two examples for this type of decision. The first is referred to as a utility 
maximizing choice. This type of decision is most applicable to the small firm. In this situation, profit is only one element; other factors such as familiarity with the environment or social benefits are examined. The second is a nonprofit decision. Hamilton (1974a) attributes this type of choice to large corporations. In this case, elements such as growth, security, and self preservation are more important than profit maximization.

A major area of inquiry is risk reduction. The assumption is that firms prefer stable environments. Every business decision involves a degree of risk. The objective is to weigh the relative returns against the risk of failure. The more control a firm has over its environment the more it can reduce the risks involved in decisions. This desire to minimize risk is used to explain the increasing number of business mergers and acquisitions (Lever, 1985). By becoming larger, firms increase the area of control and theoretically minimize risk.

Most studies of industrial movement incorporate all of these findings to explain spatial shifts. Townroe (1969) outlines two factors to explain relocation: internal and external pressures. Internal pressures arise from decisions made by management that relate to growth in output and the need for more space. These pressures are grouped into four broad categories: marketing, production, labor management, and financial policy. An increasing market or the desire to expand into additional market areas places demands on production. The increase in output leads to overcrowding and a need for additional floor space. In order to meet the increased demand, personnel decisions must be made. Management must have the ability to recruit and retain skilled labor. The desire to maximize floor space may 
involve technological innovation. Innovation requires capital and this is dependent on past investment decisions.

Changes in the costs associated with production, which are beyond the control of management, are known as external pressures. These pressures are more dynamic. They include changes in labor attitude or militancy and changes in the prices of raw material or transport costs. External pressures also reflect changes in the environment. Additional competitors or changing government policy are two examples. Townroe also places the changing attitudes of managers into this category. These are especially important in the case of new ownership or after a corporate takeover.

Townroe's concept of external pressure has been supported and expanded upon by other researchers. Chapman and Walker find that city size can be interpreted as an external pressure.

In large cities . . there is frequently pressure on sites because of demand for commerce or even housing $(1987$, p. 48).

Hamilton and North emphasize the role of government and government policy on the changing spatial character of industry. Hamilton (1978) extends the impact of government to the international level.

Townroe (1969) maintains that internal pressures are the most frequent reason for a relocation decision. Growth in output and expansion provide the incentive to move. Other researchers stress additional concerns. Keeble (1968) indicates relocation is only considered when pressures become too great to resist. The movement of industry is expensive and undertaken only when all other options have been exhausted (North, 1974). 
For all the advances the behavioral approach has offered it has not been immune to criticism. Massey (1984, p. 50), a structuralist, finds the behavioral approach to be 'simple description'.

\section{Marxist Structural Approach}

Structuralist theories developed during the late 1970's. This approach is a response to the perceived shortcomings of both the behavioral and neoclassical approaches to the industrial structure. Both the neoclassical and behavioral approach tackle the question of location from a managerial perspective. The presumed goal(s) of the firm's decision makers defines the best location. Structuralists find this approach to be inadequate, in that it fails to take a wide view of macroeconomic and social forces.

Structuralism in industrial geography uses a Marxist framework. The industrial structure encompasses two elements, capital and labor, which are usually in conflict. The focus is on the role of large capitalized corporations which use their economic and political power to dominate their work forces and the role of organized labor in responding to this control. The dynamics of these groups explains the changing pattern of industry (Lever, 1985).

Storper (1981) emphasizes the Marxian theory of crisis to explain the changes in the location of industry. This theory focuses on the expansionist tendency of capital. The goal of capital is wealth accumulation or reproduction. The expansion of capital, however, is not unlimited; two significant barriers are encountered (Lebowitz, 1976). These barriers are products of the system. The initial problem is that expansion, increased production, is dependent on increased consumption. The second is the barrier of exchange. Producers strive to keep labor costs at a minimum. This 
limits the buying power of labor, and market demand is therefore controlled. These barriers cause the process of capital accumulation to degenerate into open crisis (Storper, 1981).

Crisis is revealed in the falling rate of profit. To combat this, firms attempt to raise production. This crisis management often results in locational change. Massey and Meegan (1979) examine the relocation of the British electrical engineering industry using this structural view. The movement of industry is explained as a consequence of the changing economic environment. In this case, the changes manifest themselves in the shrinking demand for electrical equipment (Chapman \& Walker 1987, p. 125). Spatial adjustment is an effect of nonspatial changes in the economic environment (Massey \& Meegan, 1979).

In addition to the macroeconomic perspective, Marxists stress the impact of corporate policy on the labor force. Massey and Meegan (1978) describe industrial movement by examining the changing pattern of employment. They argue that changes in the national economy are important considerations when explaining the loss of inner city jobs. Massey and Meegan find the dominant process affecting cities are responses to problems of overcapacity and technological change. These technological changes are often less labor intensive and consequently influence the spatial dimension of employment. Companies seeking to reduce capacity place considerable emphasis on capital vintage. Older plants are most susceptible to closing (Massey \& Meegan, 1978). They are less technologically advanced and more expensive to maintain. 
New locations are established outside the city. This is primarily a result of the firm's ability to control the labor market. In large cities, a single firm cannot influence or control the labor market. Plants are susceptible to high turnover rates in these situations. A large plant in a small urban area can dominate and control the labor supply. These areas are likely to experience lower wage and turnover rates (Lever, 1978).

Structuralist theory has one major advantage over neoclassical and behavioral approaches. It addresses the industrial environment within a broad perspective.

... the chief merit of the Marxian approach ... is its breadth which permits industrial location to be analyzed as an integral part of the totality of economic, social and political processes (Smith, 1981, p. 142).

But structuralists cannot claim that they are the first to do so. McNee (1960) proposed the need for a broad perspective when examining large corporations.

System Approach

System theory is a reaction against reductionism. It is an approach very similar to the concept of the organism and Ganzheit or wholeness (HoltJensen, 1980). The aim is to provide a faithful representation of the interactions within a system, rather than extract a few simple relationships that can be submitted to empirical testing. Smith recognizing the need to study location using a broad framework maintained that:

... to focus attention on individual components . . is a classic case of failing to see the wood for the trees $(1979$, p. 55). 
Hamilton offers a formal definition for the industrial system. He maintains that:

a system consists of a set of 'actors' that (a) functions together (b) through various types, degrees and directions of linkages, demands outputs from and supplies inputs to other actors, and (c) behaves in particular ways as a result of interaction between either the whole set of actors or between certain groupings of them on one hand, and the 'environment' on the other (1974b, p. 5).

The key element is that industry does not function in isolation, but is part of a wider environment that influences its character.

To date, industrial geographers have only developed broad theories of industrial systems. These theories do not formally address relocation. The following is discussed to relate the present condition of system analysis in the field of industrial geography.

The broadest attempt to formulate a framework for industrial system analysis is that of Hamilton and Linge (1979). The industrial system is made up of three elements, the operating units or 'actors', the functional relationship between the units and the interactions between the units and the environment. The actors and the functional relationships between them form the internal system.

Hamilton and Linge use this system to explain the world's industrial framework. They address not only the capitalistic but also socialistic attributes of the world system. The emphasis is on large corporations, the international market and the influence of national policy. 
MoNee (1974) takes a limited view of industrial systems. He argues for the adoption of a system approach to understand the behavior of large corporations. The area of study is limited to an organization and its environment. He contends that emphasis has been placed on the individual rather than formal organizations. The work of McNee traces the development of a firm. He establishes a hypothetical company and follows its growth into a multinational corporation.

The actual system is natural. The emphasis is on the survival and development of the organization. Within this approach corporate reorganization is viewed as an adaptive response to the stresses and strains of the system (1974, p. 64). This is contrasted to the rational approach where the corporation uses its bureaucratic structure to carry out goals efficiently which is very similar to traditional economic theory. McNee argues that the corporation:

... was too valuable as a productive 'going concern' to be allowed to flounder. (It) . . . had begun to take on the characteristics of a long lived social institution. . . Much was expected of it; much was given to it $(1974$, p. 59).

The development and form of the corporation is the result of adaptive responses to the strategies of the system. The goal is to produce equilibrium. Locational choice, be it a new facility or branch plant of relocation, is based on the desire to maintain equilibrium. Decision makers must weigh which location would generate the fewest stresses or negative effects within the system. In this respect, McNee's corporate system borrows heavily from the behavioralist concept of risk reduction. 
There are major criticisms to systems research. A substantial problem is that the only measurable elements are those ascribed to previously defined methods, the new factors are qualitative and intangible. Chisholm states to:

concentrate our analysis upon the processes and relationships that exists within and between systems is nothing but plain common sense (1967, p. 51).

As of 1977 no study was found that applied systems concepts to the location of manufacturing (Miller, 1977). In addition, Storper (1981) demonstrates there has been a failure to develop a clear statement of the analytical framework within system studies.

In response to the methodological criticism Hamilton and Linge (1983) suggest the different approaches be integrated into a systems framework. They argue that behavioral changes can be nested within the neoclassical approach. They further argue that because the neoclassical approach takes place within the capitalistic environment it can be analyzed through a structuralist approach. Watts (1987, p. 15) challenges this suggestion. $\mathrm{He}$ maintains that each approach incorporates a different methodology, neoclassical and behavioral adopt a positivist method while Marxist structuralists use the structuralist method. Watt emphasizes that these frameworks are not compatible. 


\section{THE CANNING PROCESS}

To analyze effectively the location and relocation of an industry it is imperative the study is as specific as possible to a particular branch of production. Each branch of manufacturing has a set of critical locational factors. Especially important in analyzing the canning industry are the seasonal availability and perishability of the raw material. These conditions form the bases for the other features of the industry. A basic understanding of the processes of this industry will make clear the reason for the approach of this study.

Literature on the canning industry is scant. The research is narrowly focused emphasizing either the technical processes or the status of the industry in general. This chapter will explain the physical and locational needs of the industry. First, the canning process is discussed. This includes the financial needs as well as the physical processes necessary to can fruit and vegetables. The product will be followed from the field through the cannery. Then, the locational needs of the industry are addressed.

The viability of canning as an industry is based on obtaining maximal efficiencies in several processes: harvesting, sorting, and cleaning of produce as well as the actual canning process.

\section{Finance}

Processing operations are geared to sales. The overall processing program is planned to move the total pack profitably during one calendar year. Very few processors have the finance to carry inventories of any size year round. Banks, until the early 1970's, were quite liberal with well managed processors. Credit was easily obtained to carry inventories on a 
yearly basis. Typically banks would lend up to $65 \%$ of the market value of inventories. Loans were usually due for inventories over one year old. This placed the burden of finance back on the processors.

\section{Harvesting}

Practically all fruits and vegetables grown for processing in California are grown under a grower contract. Generally once the relationship between grower and processor is established, its continued for many years. Contract requirements such as size, maturity, acceptable deformities and insect damage are usually held constant. Only seasonal changes, such as price per ton and tonnage contracted, make up the yearly difference in the contract. The relationship between growers and processors are good throughout the industry.

The University of California has greatly contributed to the development of new varieties of produce that are more acceptable for processing. In the early 1950 's very little thought was given to tomato varieties best suited for the fresh market, peeled canned tomatoes and tomato paste. Today there are definite varieties adaptable for each of these commodities. This research has also included the development of new varieties of asparagus, carrots, peaches, plums as well as a number of other products.

Fruit and vegetables reach the peak of quality at a specific time. The growing of fruits and vegetables for food processing has become an efficient streamlined process. Given the conditions of the soil, location, water availability and the time of planting, farmers can ensure continuous supply 
of high quality produce (Woodroof, 1988, p. 135). Today it is not uncommon to produce three or more crops within a two month interval.

The produce must be harvested at the peak of maturity. The complexity of farming enables canners to receive a continuous supply of "ready" material. The development of mechanical harvesting equipment has greatly aided this process. These machines have revolutionized the industry. Farm produce can be grown and harvested cheaply and maintain a high degree of quality.

In order for the processor to extend the processing season, produce is often contracted in the southern areas where harvesting is done early. Tomatoes for processing are grown as far south as the Imperial Valley and north to the Sacramento Valley. The efficiency of a longer operating season offsets the cost of the longer haul of raw product.

The harvesting of vegetables should occur when they are tender, before any portion becomes fibrous and tough. Asparagus stalks should be fiberless and celery firm. Beets should have a dark red appearance, carrots tender and full of color. The harvesting of fruit is based on product size rather than flavor maturity. Figs are picked when they are firm. This is critical; if they are underripe the flavor is unacceptable, if overripe they are too soft to withstand processing. 'Royal Ann' cherries are grown for canning; they are made into maraschino cherries. They are harvested on the basis of size. Peaches are harvested when they attain the appropriate yellow skin color, pears when they are the correct size and green color. Pears are harvested when mature but still quite green and firm. They are size graded and placed in storage with controlled temperature and humidity until ready to process. 
Early deliveries are usually less mature that later ones and require up to nine days to ripen for processing.

Ideally, once harvested, mature produce, especially vegetables, should be canned within hours. This ensures product quality and reduces operating losses (Woodroof, 1988). Currently all tomatoes and carrots grown for food processing are mechanically picked. Tomato harvesting involves cutting the bush at ground level. The plant is then shaken, freeing the fruit from the vine (Woodroof, 1988, pp. 152-153). This operation is based on the premise that the mature fruit will separate easily, thus easing the sorting process. Nevertheless, additional wastes are generated as pieces of the vine as well as dirt are often mixed with the fruit. In addition to the increased waste content, mechanization also increases the probability of damaging the fruit. Delivery

All farm produce used in processing goes through the same basic steps in preparation for processing. The delivery is weighed and quality graded on receipt to conform to the grower contract. Weight and grade documents are produced in duplicate for delivery to the grower, trucker and processor. Much of the process is supervised by the State of California. Washing

After harvesting, the fruit is transported to the cannery, where it is cleaned. This is essential. The process involves immersing the product, especially tomatoes, in water to remove dirt, seeds, and pesticide residues. After the initial wash, the product is then sprayed with a high pressure rinse to remove any remaining residues. 


\section{Sorting}

Once harvested and washed, the fruit is sorted. All produce is inspected for overall quality, size and maturity. Quality and weight standards have been established on all processed foods by the United States Department of Agriculture. Products packed must conform to the U.S. Standards of Identity for quality. These standards are fancy, choice, standard and mixed and irregular. All standards for quality must be clean and wholesome and processed without alterations. Bruised, diseased, and unripe products are separated. Bruises are trimmed from the fruit and discarded along with immature produce.

Mechanization has increased dramatically. Traditionally all sorting and trimming was done by hand. In modern facilities it's done almost entirely by machine. New technology enables machinery to distinguish quality and maturity by examining weight, chemical content, and using photoconductive cells. Hand sorting is almost exclusively limited to the final inspection. This is done just before the product is packed. The new machinery reduces operating costs and increases the volume of production. Preprocessing

Preprocessing involves preparing the produce for canning. Once washed, many fruits and vegetables require peeling. Vegetables are often blanched to reduce the leaching of nutrients.

Machines are used to peel resistant products such as beets and carrots; however, soft produce is most commonly peeled using hot lye solutions. Peaches, apricots, and tomatoes are immersed in these solutions. The fruit is then agitated and subjected to high pressure sprays that remove the skins. 
The produce then travels through two washing baths to remove any caustic residue.

Blanching vegetables involves conveying the produce through hot water or steam. This subjects it to a specific temperature, usually $190^{\circ} \mathrm{F}$ $\left(80^{\circ} \mathrm{C}\right)$. This expels gases, air, inactivates enzymes, and arrests changes in flavor (Luh \& Kean, 1988, p. 199). It also softens the vegetables, enabling more to be filled into each can.

Packing

After preparation the produce is placed into metal containers. The cans are run on automatic conveyors and washed with hot water or steam. The product is filled in the containers then juice or syrup are added. Containers are marked by code to identify their contents, packer and date of processing.

Each can is then sealed. To achieve a vacuum seal one of two methods is employed. The first involves subjecting open cans to heat to expel air. The cans are then sealed and a vacuum is formed. The second involves sealing the containers within a vacuum chamber. The sealed can is heat processed until completely sterile.

\section{Post-production and Cleanup}

Cans that are sealed using heat or items that are cooked in the can in continuous cookers require immediate cooling. Can cooling is done by either spraying the cans with cool water or by replacing the water in the continuous cooker with cool water. They are then stored, labeled and packed for shipping. 
Cleaning is an ongoing process in every cannery. Cleanings are short term and involve every process of the canning operation. Chemical compounds and water are the primary solvents used in this endeavor. Location Requirements

The canning industry has very specific locational requirements. Luh, Kean and Woodroof (1986) argue that the factors determining a suitable location are availability of raw products, an adequate supply of water, the availability of labor during the canning season and adequate facilities for the disposal of plant waste. They also state that the plant should have ample space.

The most crucial requirements are the access to produce and the availability of water. The availability of raw products is essential. The canning process is most efficient when the raw product can be harvested and canned within hours. As stated previously, this ensures the highest quality of finished product. An adequate supply of water guarantees a continuous canning operation. Larger canneries, at the peak of the season require $5,000,000$ gallons of water a day (Hernandez, 1977). Mercer, Rose, Butler and Appleman (1958) established that over 3000 gallons of water are required to process one ton of tomatoes. California yearly processes more than 7 million tons of tomatoes (Almanac, 1989). The water demands of the industry are tremendous.

An adequate labor supply cannot be overlooked. The labor factor is important because, despite the industries increased mechanization, it still requires large labor inputs for trimming and quality control. 
The industry also generates huge volumes of organic waste. Facilities that can handle large deposits of waste water on a continuous basis are essential.

\section{Factors of Production}

The canning industry in Santa Clara County is no different from the industry at large. It is affected by changes in agricultural productivity, the availability of labor, and changes in the cost of sewage treatment. In addition changing government policy and the management of large cooperative canning operations have had a substantial impact on the canning industry in Santa Clara County. 


\section{METHODOLOGY}

The study of industrial decline and movement has produced varying theoretical and methodological approaches. Of the five discussed, four were found to be inappropriate for this study.

Both economic and neoclassical theory are based on the assumptions of economic rationality. Events and location are explained by examining only economic factors. The influence of government policy and large corporations, or cooperatives is overlooked or seen as insignificant.

Structural and system theories are also inappropriate. Marxist structural theory is beyond the scope of this study. Its emphasis is on the dynamics of labor and capital at the macro level. The concept of studying a problem in whole as opposed to insularly holds great promise but unfortunately, system theory has not been adequately developed. The existing works emphasize either the industrial structure as a whole or independent large corporate systems. A specific methodology has not yet been formulated.

Theoretical Perspective

The behavioralist approach is best suited to explain the decline of the canning industry in Santa Clara County. Within this perspective, Townroe's (1969) theory is most applicable to this study. The behavioral perspective stresses the decision-making process and the factors that influence it. Townroe emphasizes that the decision of an industry to relocate, in and of itself, should not be the focal point of study. Research should seek to understand the reasons for the move. The factors, as outlined by Townroe, are either controlled by the industry (internal) or are beyond the industry's 
realm of influence (external). Both have an effect on the industry, but of the two, internal influences are the most influential.

Factors that are internal to the canning industry include labor cost, finance and innovation, and the desire to increase production. External pressures include changes in government policy, agricultural production and sewage costs as well as the changes in the attitudes of the managers of large cooperatives.

Townroe's theory has received wide recognition and support. The basic principles have been applied to a variety of work. Green and Cromley (1982) cite Townroe in thier work on horizontal mergers and their impact on the spatial distribution of employment. The study supported the idea that the final location decision is of less importance than the reasons behind the decision. Hayter (1978) also addresses Townroe's work. Hayter argues for analyzing the location decision in stages to better appreciate the process. Auty's (1975) attempt to classify factories by examining building vintage also incorporated Townroe's ideas.

\section{Research Procedure}

The first step was to define fruit and vegetable canning. This was done using the United States Census of Manufacturers Standard Industrial Classification 2033, canned fruit, vegetables, preserves, jams and jellies. This includes processors engaged in canning fruits and vegetables as well as fruit and vegetable juices. It also encompasses the manufacturing of catsup, tomato sauces, preserves, jams and jellies. It does not include canned seafood, baby food, soups, dehydrated, pickled or brined fruit and vegetables. 
Frozen fruit and vegetables are also excluded. This definition will apply to the rest of this work unless otherwise noted.

Once the industry was defined, the factors which most dramatically affect its operation were identified. There were found to be water, waste disposal, labor and the availability of fresh produce. Secondary factors include the organization of the industry and the policy of local government.

Data were sampled from several sources. The United States Census of Manufacturers provided data for the number of canneries, employees, and cost per employee. Agricultural acreage was derived from the Santa Clara County Department of Agriculture's Agricultural Crop Reports. The cost of sewage treatment was provided by the San Jose/Santa Clara Water Pollution Control Plant. The data were drawn based on the Census of Manufactures reports to provide homogeneity to the data set. Data were sampled in five year intervals, beginning in 1967 through 1987.

The data were then subjected to Pearson's Product Moment Correlation (PPMC), to assess the degree of correlation each factor had to the industry's decline (Figure 4.1).

$$
r=\frac{\sum_{i=1}^{n} X_{i} Y_{i}-\left(\sum_{i=1}^{n} X_{i}\right)\left(\sum_{i=1}^{n} Y_{i}\right) / n}{\sqrt{\sum_{i=1}^{n} X_{i}^{2}-\left(\sum_{i=1}^{n} X_{i}\right)^{2} / n} \sqrt{\sum Y_{i}^{2}-\left(\sum_{i=1}^{n} Y_{i}\right)^{2} / n}}
$$

Figure 4.1 Pearson's Product Moment Correlation Coefficient

The effects of government policy and large cooperatives do not lend themselves to statistical manipulation. The significance of these variables 
was explained based primarily on interviews with people familiar with the County's canning industry.

The canning industry presents special problems for intensive study. It is an industry tied to agriculture and not to traditional manufacturing. Initially the industry located in areas of great agricultural production, areas where overall populations were small. Santa Clara County was such an area. It was not categorized as a significant industrial area until 1958. Industry group data were not provided by the Census of Manufacturers until 1967. An additional problem is tied to the seasonal nature of the industry. Employment reaches a peak during the summer months. Census data reflect yearly totals. The result is that the actual employment for this industry is under reported. The intent of this research is to show the overall trend of the industry; therefore, Census data were adequate.

Historical information was taken largely from newspaper reports and historical works of the Santa Clara Valley. Key contributors include Jacobson (1984), Claus (1966), Griffin and Chatham (1958) and Broek (1932). 


\section{LANDSCAPE CHANGE 1930-1987}

The analysis of an industry is most effective when both the industry and area are examined within the context of one another. The decline of the canning industry is part of the broader social change brought on by the change in the economy of the County. The change in the County's landscape is presented in order to make the examination complete.

\section{Location and Climate}

Santa Clara County lies immediately south of San Francisco Bay. The western boundary is the crest of the Santa Cruz Mountains, the eastern boundary lies along the crest of the Diablo Range. The southern border is formed by the Pajaro River.

Between the two mountain ranges lies the Santa Clara Valley. It extends from the southern edge of the San Francisco Bay to the Pajaro River and is composed of fairly deep rich alluvial soils. At Coyote, the two

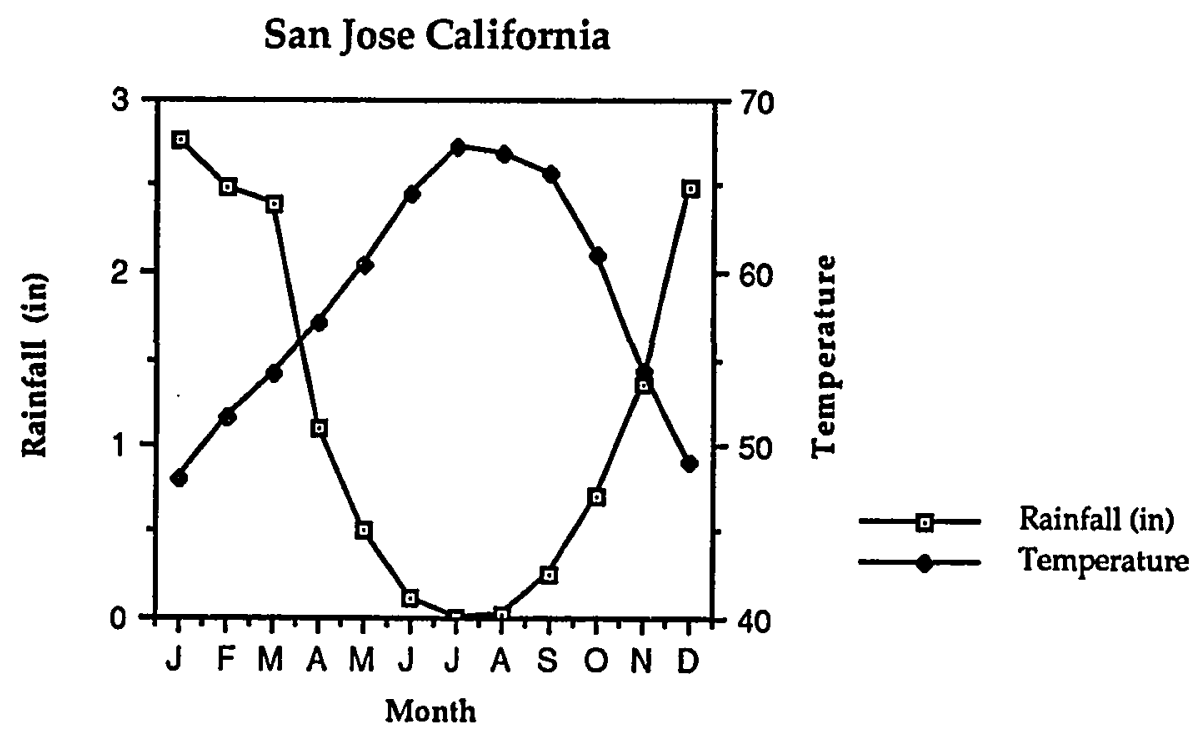

Figure 5.1 Climograph of the Santa Clara Valley 
mountain ranges nearly converge, and the Valley narrows considerably. It later widens slightly near the City of Gilroy.

The County's climate can be generally described as Mediterranean. It is a west coast subtropical climate analogous to Köppen's Csa designation. Rainfall averages 15 inches a year and is concentrated almost entirely during the winter months (Figure 5.1). The summer months are very dry. Average temperatures range from $38^{\circ} \mathrm{F}$ in the winter to $80^{\circ} \mathrm{F}$ during the summer.

The County's climate is dramatically influenced by the surrounding mountains. The Santa Cruz Mountains experience slightly cooler temperatures and markedly higher rainfall totals. The Diablo Mountains receive slightly less rainfall and experience warmer temperatures.

\section{Orchard Landscape}

In the 1930's, the agricultural landscape was dominated by orchards. Nearly 190,00 acres were devoted to bearing fruit and nut trees (Figure 5.2).

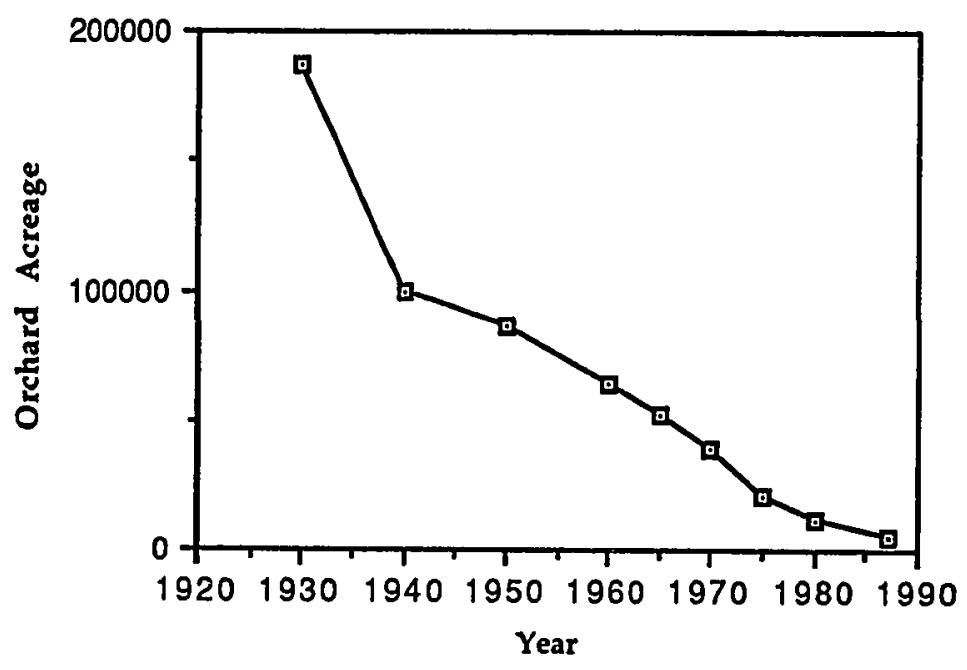

Figure 5.2 Santa Clara County's orchard acreage. Sources: Broek, 1932, p. 104 and San Jose Chamber of Commerce, 1986, p. 12. 
The predominant fruits were apricots, cherries, pears, and prunes. The orchards were most abundant in the northwest portion of the Santa Clara Valley (Figure 5.3). This is attributable to the area's climatic conditions. The area is mostly sunny and spring frosts are infrequent (Broek, 1932, pp. 137139). These characteristics favor the growth of fruit trees.

The most important influence for the location of cities and towns was the El Camino Real highway. The County's most important railroad paralleled the road route. Small towns developed along this traffic artery. Vast orchards tilled virtually all the area between each town.

San Jose was the most diversified urban area. Broek (1932) provides an excellent description of the Valley's central place. The central business district formed the center of the City. It offered a variety of retail outlets, banks, theaters and office space. The buildings were very close together, often attached. The crucial need for central space served as an impetus to build vertically. Around this central core were light industries, apartments and a mix of administrative units. Examples include schools and churches. Heavy industry located along the railroads, the only method at the time of transporting bulk freight. The highway was primarily used for passenger traffic. During the 1930's the total population of the County barely exceeded 145,000 as compared with a 1990 figure of $1,467,700$ (Figure 5.4).

In smaller towns, businesses located along the major throughways adjacent to the El Camino. The retail areas were located in the center of town with light industry at the town's edge. These smaller towns offered very few services. They were almost exclusively retail trade nodes. 


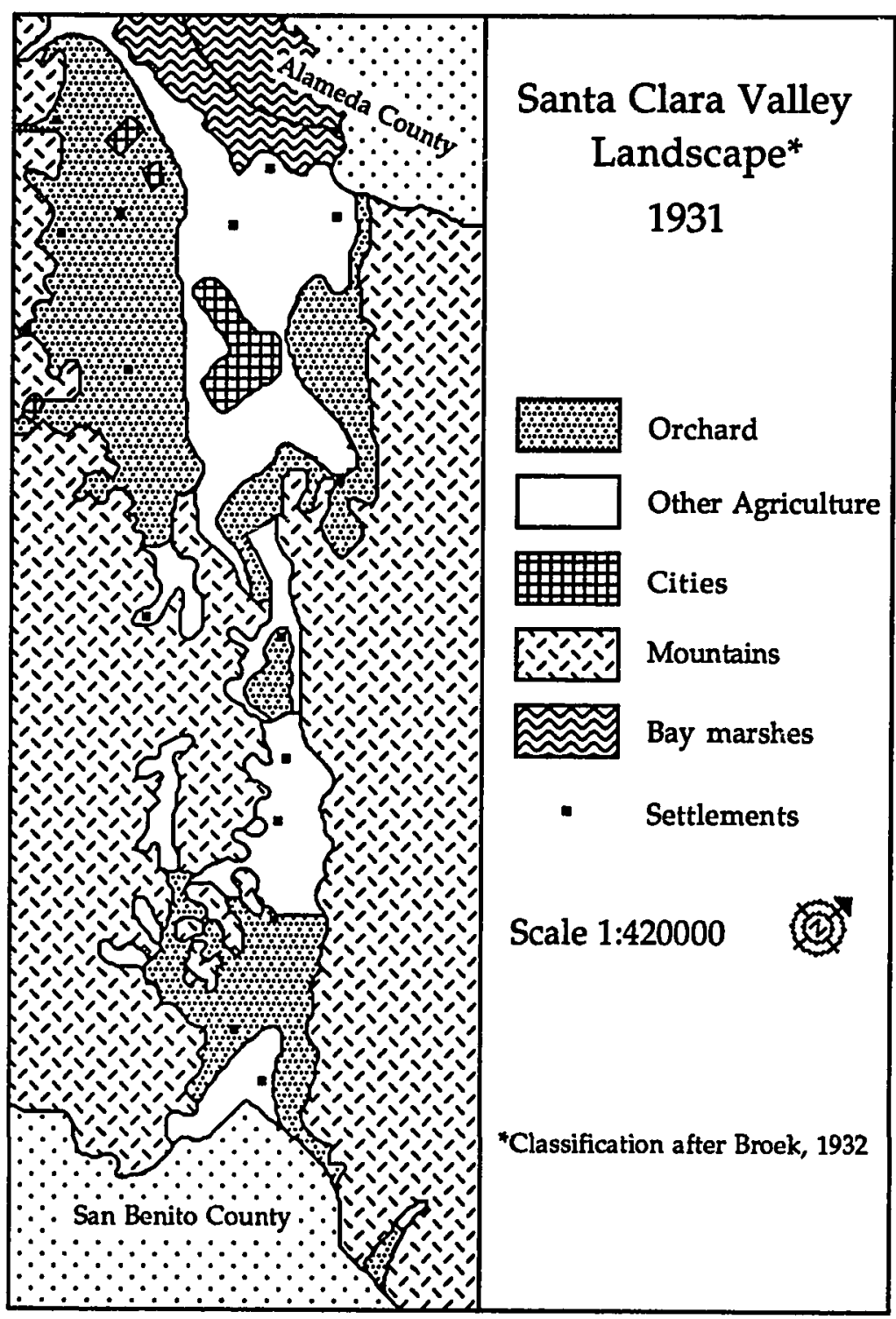

Figure 5.3 Santa Clara County land use 1931. Source Broek, 1932. 


\begin{tabular}{|c|c|c|c|c|c|c|c|}
\hline & 1930 & 1940 & 1950 & 1960 & 1970 & 1980 & 1990 \\
\hline Alviso & .38 & .67 & .70 & 1.2 & - & - & - \\
\hline Campbell & - & - & - & 11.9 & 24.7 & 25.5 & 35.3 \\
\hline Cupertino & - & - & - & 3.7 & 18.2 & 35.2 & 39.9 \\
\hline Gilroy & 3.5 & 3.6 & 4.9 & 7.3 & 12.6 & 21.6 & 30.4 \\
\hline Los Altos & - & - & - & 19.7 & 24.9 & 26.1 & 26.2 \\
\hline Los Altos Hills & - & - & - & 3.4 & 6.8 & 7.6 & 7.3 \\
\hline Los Gatos & 3.2 & 3.6 & 4.9 & 9.0 & 23.7 & 28.2 & 26.8 \\
\hline Milpitas & - & - & - & 6.6 & 27.1 & 35.7 & 50.3 \\
\hline Monte Sereno & - & - & - & 1.5 & 3.0 & 3.4 & 3.3 \\
\hline Morgan Hill & .9 & 1.0 & 1.6 & 3.1 & 6.5 & 16.6 & 22.9 \\
\hline Mountain View & 3.3 & 3.9 & 6.6 & 30.9 & 51.1 & 58.2 & 65.4 \\
\hline Palo Alto & 13.6 & 16.8 & 25.5 & 52.2 & 55.9 & 54.1 & 54.8 \\
\hline San Jose & 57.7 & 68.5 & 95.3 & 204.2 & 445.8 & 610.4 & 765.2 \\
\hline Santa Clara & 6.2 & 6.7 & 11.7 & 58.9 & 87.7 & 85.0 & 92.1 \\
\hline Saratoga & - & - & - & 14.8 & 27.1 & 30.1 & 27.9 \\
\hline Sunnyvale & 3.1 & 4.4 & 9.8 & 52.9 & 95.4 & 107.2 & 115.6 \\
\hline Unincorporated & 53.3 & 65.8 & 130.0 & 161.0 & 154.2 & 120.3 & 104.3 \\
\hline Total & 145.18 & 174.97 & 291.0 & 642.4 & 1064.7 & 1265.2 & 1467.7 \\
\hline
\end{tabular}

Figure 5.4 Santa Clara County's population (1000's of people).

During the early part of the century the economy of Santa Clara County was driven by agricultural. Manufacturing, retail trade and employment depended on agricultural production. Cities and towns were defined by the areal extent of the city's structures. This characterized the area until World War II. For a more detailed examination of the 1930's landscape refer to Broek (1932). 


\section{Suburbanization}

The orchard landscape began to give way to urbanization in the mid 1940's. This can be seen in the acreage trends in figure 5.2. The reduction in fruit acreage between 1930 and 1940 is evidence of this. This loss, although dramatic, is exaggerated by the two data sets used to compile the figures. Broek (1932) relied on U.S. Census of Agriculture Farm Type data. The following years were compiled from the Santa Clara County Agricultural Commissioner's data.

After World War II manufacturing and trade replaced agriculture as the areas chief source of employment. In 1949, manufacturing employed 20,900 while agriculture employed 16,400 (Figure 5.5). The disparity between these two categories increased with time.

\begin{tabular}{|r|r|r|r|r|r|r|}
\hline & Agriculture & Manufacturing & Trade & Service & Government & Total \\
\hline 1949 & 16.4 & 20.9 & 16.5 & 11.5 & 11.8 & 91.6 \\
\hline 1960 & 11.2 & 69.0 & 34.5 & 30.5 & 26.8 & 203.0 \\
\hline 1965 & 8.4 & 88.2 & 49.4 & 53.9 & 43.4 & 283.0 \\
\hline 1970 & 6.7 & 123.5 & 71.0 & 75.5 & 60.0 & 384.5 \\
\hline 1975 & 7.7 & 153.8 & 91.3 & 97.3 & 72.5 & 476.3 \\
\hline 1980 & 6.4 & 242.6 & 135.1 & 155.8 & 83.9 & 697.5 \\
\hline 1987 & 4.7 & 262.1 & 162.0 & 193.1 & 87.6 & 796.4 \\
\hline
\end{tabular}

Figure 5.5 Average annual employment by industry (1000's of people).

The growth in manufacturing was related to growth in the County's population. Between 1940 and 1950 the population increased 66\%. By 1960 it had grown by an additional 350,000 (Figure 5.4). As nearly all the increase was urban the huge population increase fostered the change from a rural to urban 
landscape. In the mid 1950's the number of building permits doubled (Griffin \& Chatham, 1958, p. 200).

The development of the Valley was not orderly. During the mid 1950's each community sought to firmly establish itself. Campbell, Cupertino, Los Altos, Los Altos Hills, Milpitas, Monte Sereno and Saratoga formally incorporated into cities. San Jose was the most aggressive in extending its boundary; the City pursued a policy of strip-annexation. This involved incorporating not just the street but the area adjoining it to a certain width. The result was a "helter-skelter indiscriminate pattern" of development (Griffin \& Chatham, 1958, p. 203). By 1961 the change in landscape had been significant (Figure 5.6).

Despite the significant increase in urbanization, the County maintained a strong agricultural base. In 1945, 70\% of the Bay Area's Class I farmland was located in Santa Clara County (Whyte, 1958, p. 136). In 1958, 62 major food crops were produced and the area was one of the 100 leading agricultural counties in the nation. The County was first in strawberry production as well as prune acreage and yield. It was third in pear acreage and yield and sixth in total value of fruit and nut production (Griffin \& Chatham, 1958, p. 195).

The suburbanization of the Valley continued steadily through the 1960 's and 1970's. During that time the County lost over 50,000 acres of bearing fruit and nut trees. The rate of conversion slightly exceeded 2300 acres each year. The County's population doubled from 642,400 to $1,265,200$. In 1970 agriculture accounted for only $1.7 \%$ of the County's employment. 


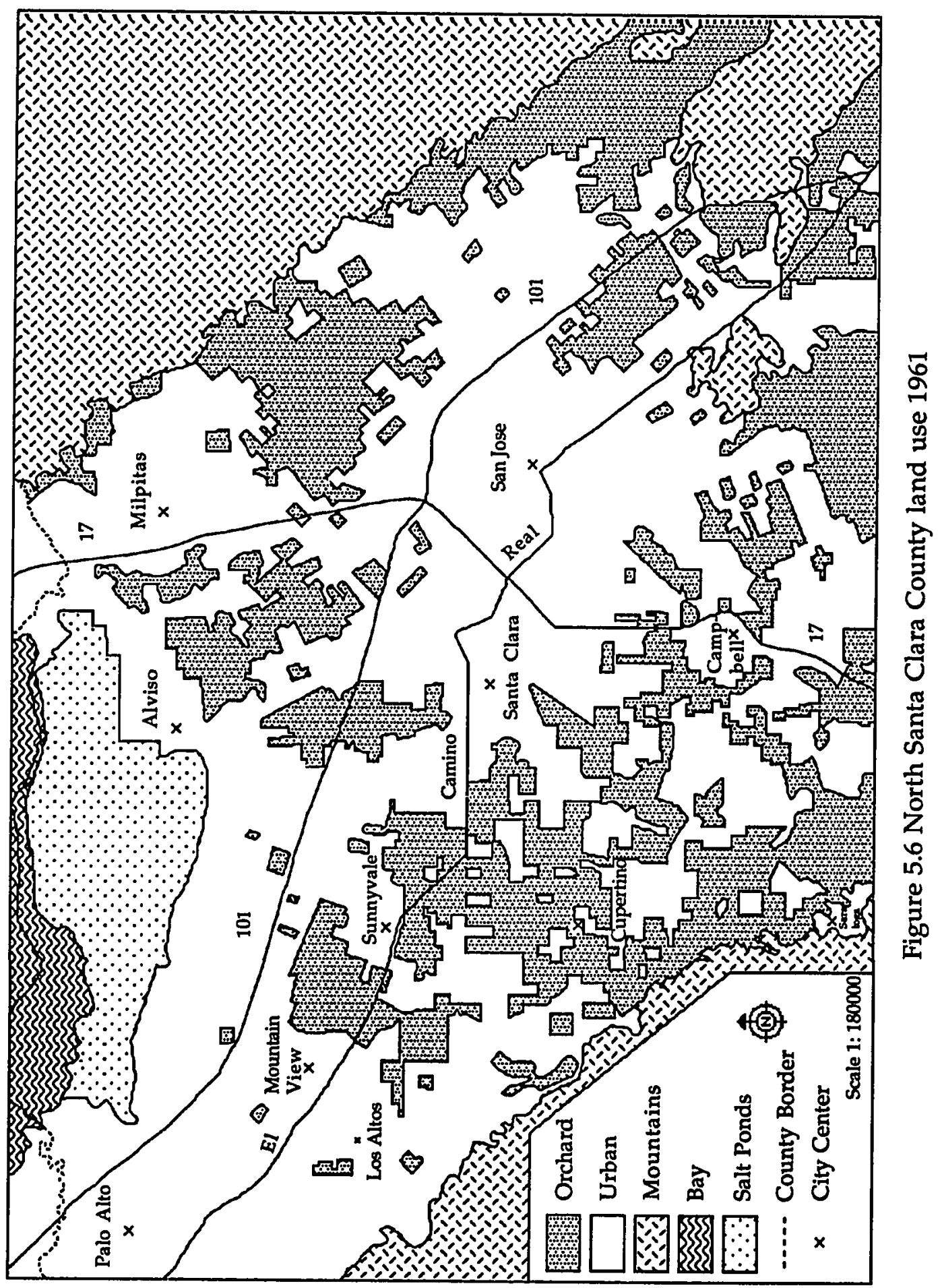




\section{Present Landscape}

The conversion from an agricultural to an urban landscape was virtually complete by 1980 . The rate of urbanization since then has decreased. The area once called the Valley of Heart's Delight is now almost completely occupied by urban land uses. The valley floor, once covered with orchards, is now a substantial urban agglomeration. The remaining orchards are small and widely spaced. The borders of cities in the north west cannot be distinguished (Figure 5.7). Expansive areas of open space no longer exist. Small centers like Evergreen, Berryessa and Alviso have formally disappeared. They've been absorbed into the City of San Jose.

Growth in the County's economy has led to the near extinction of agricultural employment. Agriculture accounts for less than $1 \%$ of employment. Manufacturing and service industries are the principal economic contributors (Figure 5.5). 


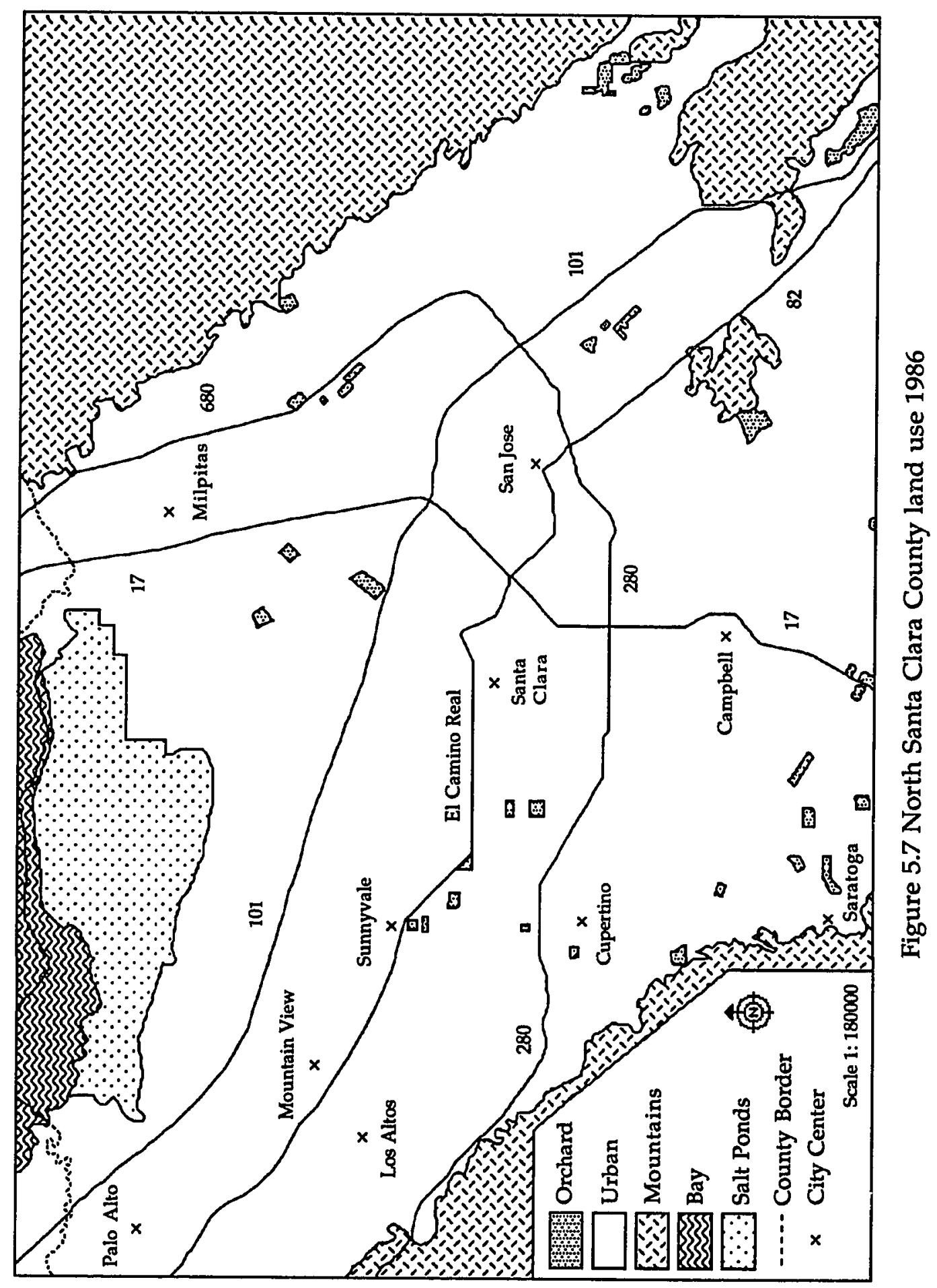




\section{SANTA CLARA COUNTY'S CANNING HISTORY}

Santa Clara County's fruit and vegetable processing industry began in the 1870 's. There is some debate whether the industry was an impetus for the planting of fruit orchards or whether the orchards gave rise to the industry. Arbuckle (1986) argues that prior to the establishment of canneries the area was dangerously close to losing its fruit orchards. The area was plagued by overproduction. Many of the apple, peach, pear, apricot and cherry growers abandoned or uprooted their small orchards. Payne (1987) argues that fruit production and the expansion in fruit acreage gave rise to the canning industry. Nonetheless, once established, the industry grew and eventually led the state in overall production.

The demand for fresh and packed fruit increased dramatically as a result of the Gold Rush and the Civil War. The Gold Rush ushered in wildly inflated prices for fruit. The Civil War and subsequent demand for storable products was met by use of the extensive railway system ("Fruit Processing," 1951). This made the markets in the east both accessible and profitable.

The first cannery was established in San Jose in 1871 by James Dawson. This enterprise was very small. The plant processed peaches, pears, cherries, apricots and plums. The first year only 350 cases were packed. In only two years the output increased to 8000 cases (Arbuckle, 1986, p. 156).

Golden Gate Packing established the second cannery in the County in 1875. The plant processed primarily peaches. The cannery is notable for its personnel rather than its variety or scale of production. It was at this cannery that Elmer Chase and Robert Bentley first worked in the industry ("Fruit Processing," 1951). Elmer Chase would later manage the Richmond Chase 
Company. In 1920 Robert Bentley would become the president of the California Packing Corporation, more commonly known as Del Monte (Braznell, 1982, p. 164).

Soon the County became the state leading producer of both fresh and canned fruit. In 1880 California's total canning pack was 221,000 cases, most of which came from Santa Clara County (Claus, 1966, p. 44). In 1890 the County was the states leading producer of fresh, dried and canned fruit ("Fruit Processing," 1951).

During the early part of the century the County continued to lead the state in overall production. In the 1920's there were 37 fruit and vegetable canneries in Santa Clara County. They were located throughout the area (Figure 6.1). At this time the County became a source of industrial research

\begin{tabular}{|l|l|l|l|}
\hline \multicolumn{1}{|c|}{ City } & $\#$ & \multicolumn{1}{c|}{ City } & \multicolumn{1}{c|}{} \\
\hline Alviso & 1 & Milpitas & 1 \\
\hline Campbell & 3 & Mountain View & 2 \\
\hline Gilroy & 2 & San Jose & 22 \\
\hline Los Gatos & 1 & Santa Clara & 1 \\
\hline Mayfield & 1 & Sunnyvale & 3 \\
\hline
\end{tabular}

Figure 6.11920 cannery distribution. Source: "Fruit Processing," 1951.

and innovation. One of the most notable contributions was the development of fruit cocktail. It was developed here in 1926 by Herbert Gray (Hawkins, 1969). Another inventor at this time was Anderson Barngrover. He developed a continuous can sterilizer. This allowed cans to be sterilized, cooked and cooled in one process. The device cut labor demands 
significantly. What once required as many as 15 men was reduced to one (Jacobson, 1984, p. 225).

In the 1930's and 1940's the County continued to be a major source of innovation as well as production. At this time, the County accounted for $90 \%$ of the states canning output (Jacobson, 1984, p. 208). It was during this period that a pear preparation machine was developed. This machine cored halved and peeled the fruit mechanically. Prior to its development these processes were all done by hand (Jacobson, 1984, p. 225).

In the 1940's and 1950's the industry's focus was on increasing production and becoming more labor efficient. World War II greatly increased the demand for canned goods but it also severely impaired labor availability (Claus, 1966, p. 46). In the mid 1940's important developments increased production with minimal labor input. Joseph Amari invented a machine to cut and pit apricots, and he also developed a similar machine for plums. Joseph Perrelli invented a device that twisted the pit from cling peaches. FMC conducted research on adopting high thermal processes to canned food (Jacobson, 1984, p. 225). This research would revolutionize the industry. These improvements firmly established Santa Clara County's position as the leader in cannery research.

During the 1950's the County packed 25\% of the states total fruit and vegetable canned products. There were 44 canneries and summer employment peaked at 22,000 workers (Bowman, 1956). This led some people to claim that this area was the single largest producer of canned good in the world. This reputation persisted into the early 1960's (Payne, 1987, p. 98). 
Since 1960, the industry has declined. In 1966, canning accounted for a smaller share of the County's total employment (Figure 6.2). Despite the decline, canning employment between 1958 and 1966 increased 15\% (Santa Clara Planning Department, 1967a, p. 19). In 1967, the County accounted for $24-30 \%$ of the states total fruit and vegetable pack and $10 \%$ of the national pack (Claus and Dalichow, 1971, p. 171;Suryaraman, 1990).

\begin{tabular}{|c|c|c|c|c|}
\hline Year & $\begin{array}{c}\text { Fruit \& } \\
\text { Vegetable } \\
\text { Processing } \\
\text { Businesses }\end{array}$ & $\begin{array}{c}\text { Total County } \\
\text { Businesses }\end{array}$ & $\begin{array}{c}\text { Fruit \& } \\
\text { Vegetable } \\
\text { Processing } \\
\text { Employment }\end{array}$ & $\begin{array}{c}\text { Total County } \\
\text { Employment }\end{array}$ \\
\hline 1929 & 58 & 296 & 7377 & 10851 \\
\hline 1958 & 61 & 773 & 8881 & 51377 \\
\hline 1967 & 48 & 1251 & 8000 & 120300 \\
\hline 1972 & 51 & 1743 & 8100 & 134900 \\
\hline 1977 & 43 & 2671 & 8100 & 181400 \\
\hline 1982 & 35 & 3326 & 6400 & 276500 \\
\hline 1987 & 24 & 3298 & 4100 & 275700 \\
\hline
\end{tabular}

Figure 6.2 County's Fruit and Vegetable Processing Industry.

At this time most of the canneries were located in the northern portion of the Santa Clara Valley. The heaviest concentration was in and around the cities of San Jose and Santa Clara. These areas alone accounted for 18 of the County's 22 canneries (Figure 6.3). The other significant City was Sunnyvale. Two large facilities were located near the City's center (Figure 6.4).

During the late 1960's, a variety of products were processed, items consisted of: apples, apricots, artichokes, asparagus, beets, carrots, celery, cherries, grapes, peaches, pears, plums, prunes, several legumes spinach, and 


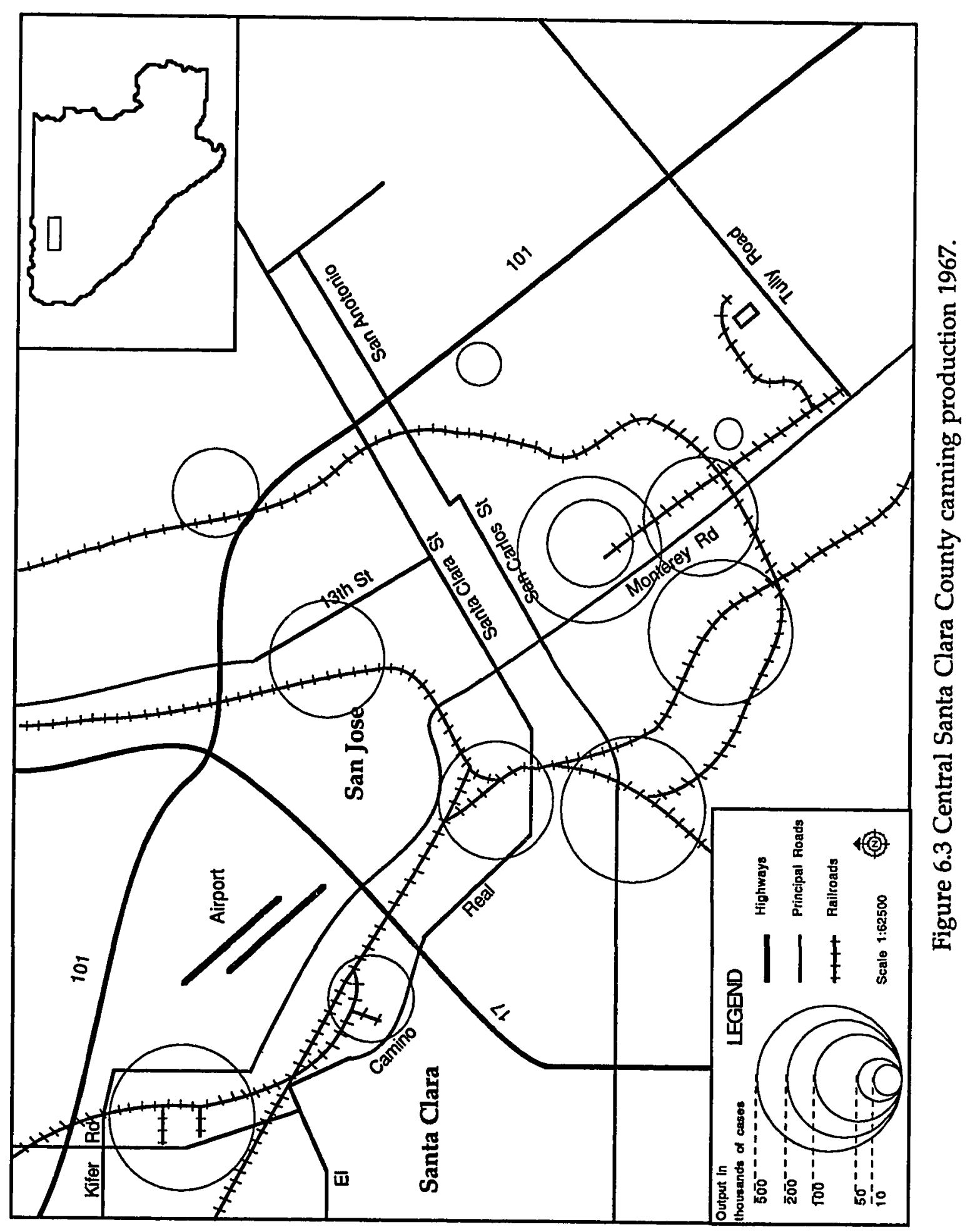




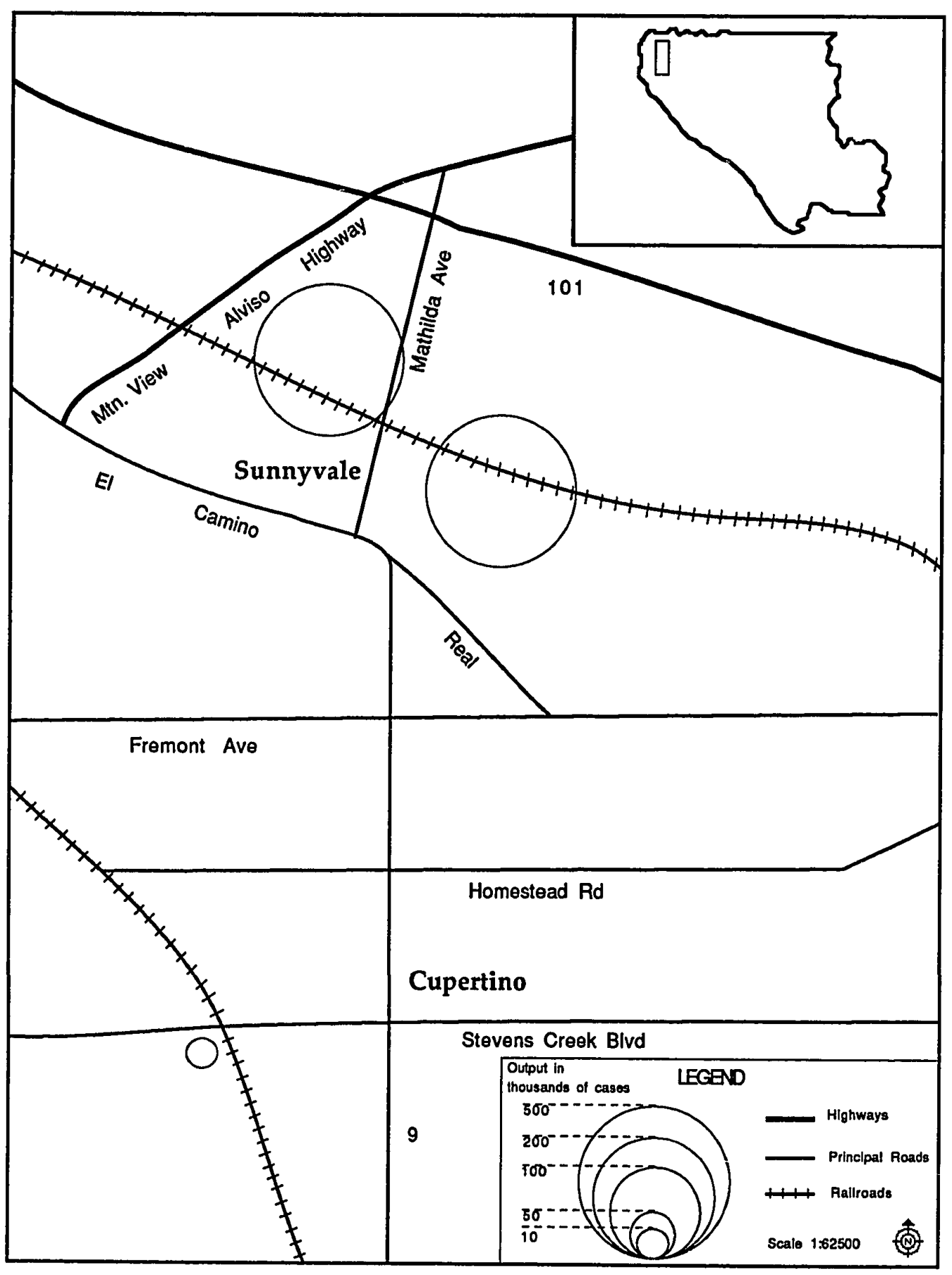

Figure 6.4 West Santa Clara County canning production 1967. 


\begin{tabular}{|c|c|c|c|c|c|c|c|c|c|c|c|c|}
\hline & 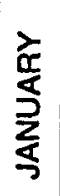 & 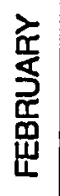 & $\begin{array}{l}\frac{T}{0} \\
\frac{\pi}{\Sigma} \\
\Sigma\end{array}$ & $\begin{array}{l}\frac{1}{\bar{\alpha}} \\
\frac{a}{\alpha}\end{array}$ & $\frac{z}{\Sigma}$ & 㞻 & うે & $\begin{array}{l}\frac{5}{2} \\
\text { త్ } \\
\stackrel{2}{\gtrless}\end{array}$ & 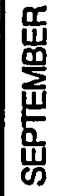 & $\begin{array}{l}\text { 恖 } \\
\frac{0}{8} \\
\end{array}$ & 䍃 & $\begin{array}{l}\text { 岳 } \\
\text { 晏 } \\
\text { 岁 }\end{array}$ \\
\hline APPLES & & & & & & & & & 5 & 3 & & Fin \\
\hline APRICOTS & & & & & & $\theta$ & & $\because$ & & & & \\
\hline ASPARAGUS & & & ; & $\therefore$ & & 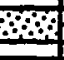 & 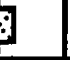 & & & & & \\
\hline BEETS & & & & & & 8 & 39 & 9 & 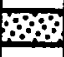 & 30 & $m$ & 8 \\
\hline CARROTS & & & & & & & & & & 8 & A & A \\
\hline CHERAIES & & & & & $\Leftrightarrow$ & & 붕 & & & & & \\
\hline GRAPES & & & & & & & & & I & 3 & & \\
\hline PEACHES & & & & & & & 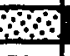 & & 8 & 6 & & \\
\hline PEARS & & & & & & & 8 & & 8 & & & \\
\hline PLUMS & & & & & & & $\theta$ & $\because$ & & 周 & & \\
\hline SPINACH & & & & & Hi & 8 & & & & & & \\
\hline TOMATOES & & & & & & & & $\therefore$ & 8 & & 3 & \\
\hline
\end{tabular}

Figure 6.5: California's fruit and vegetable canning seasons. Darkened areas depict periods of greatest productivity. Source: Luh and Kean, 1988, p. 198.

tomatoes. The variety of crops enabled canneries to operate profitably for nearly ten months each year (Figure 6.5).

By 1987 only eight canneries remained in the County. Processing was reduced to apricots, cherries, peaches, pears, prunes, and tomatoes. The canning season had been greatly reduced and the viability of the industry in this area seriously questioned.

The actual peak of the industry was during the 1940's when Santa Clara County was the Country's dominant producer of canned fruit and vegetables. 
In fact, prior to World War II the County's chief and only industrial export was processed food (Griffin \& Chatham, 1958). During the late 1950's and early 1960's the County's monopoly disappeared. Yet despite the widening of the County's economic base, canning accounted for a considerable portion of the state's output. Figure 6.6 depicts California's production of canned fruit and vegetables in 1967. It clearly depicts the significance of Santa Clara County's production.

From its inception, at the end of the nineteenth century, until the early 1960's food processing was a growing industry in Santa Clara County. The area was once important not only as a producer, but also as an industrial innovator. Since this time the industry has declined significantly. 


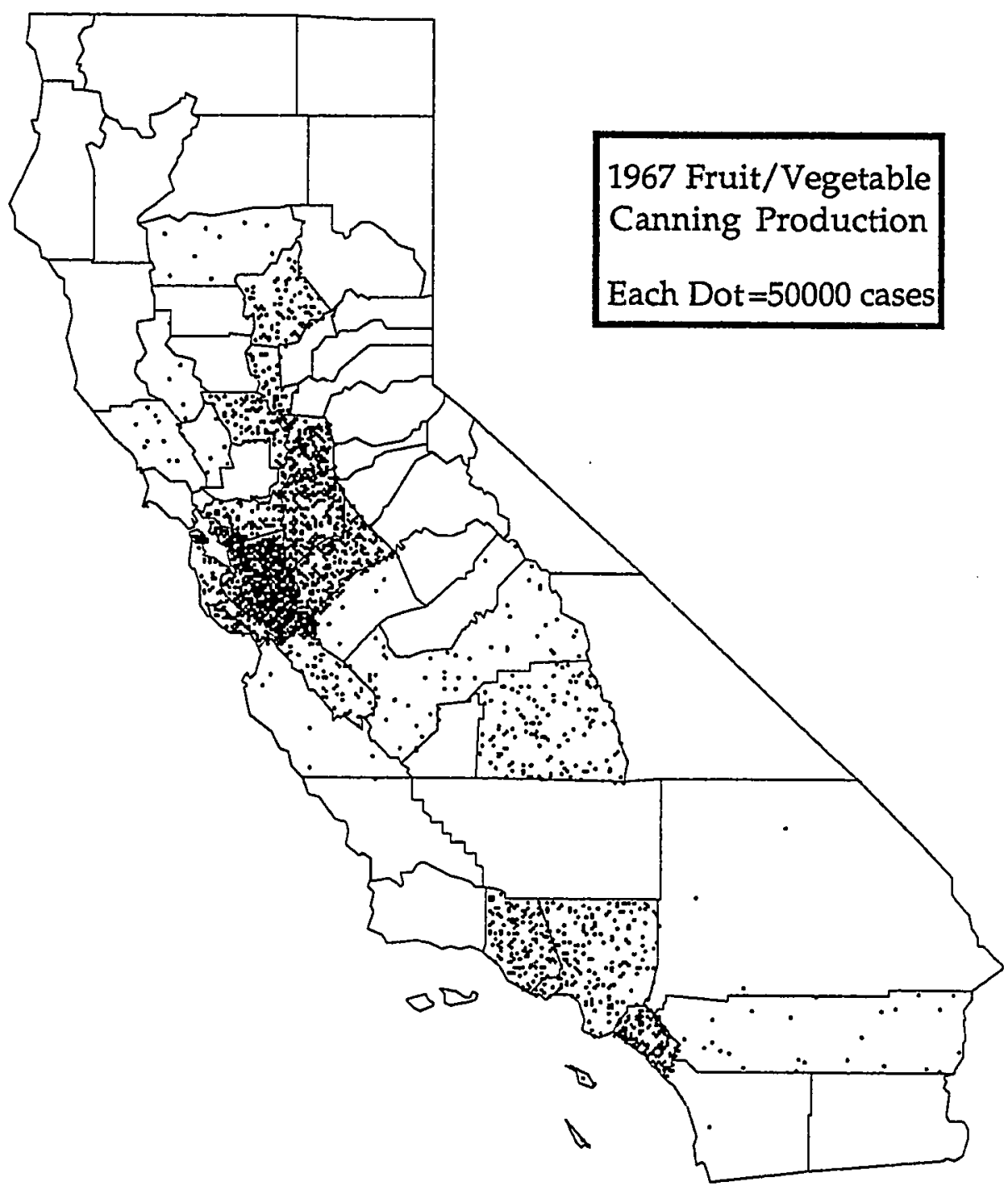

Figure 6.61967 Canned fruit and vegetable production. 


\section{RESULTS AND ANALYSIS}

The results of the research are presented in the following section. First the changes in the County's agricultural production is examined. Then, the changes in the number and cost per employee are explored. Following that are the changes in sewer rates, as well as the effect of both local and national government policy. Then, the changes within the structure of the industry are addressed. In addition to the statistical correlations, additional information relating to each factor is presented. Finally a discussion of the results is presented. This section relates the impact of the loss of the industry has had on Santa Clara County as well as the status of the canning industry in California.

\section{County Agricultural Production}

The availability of raw produce is a critical factor of location for food processing. Proximity to the field reduces the cost as well as the possibility of receiving damaged produce.

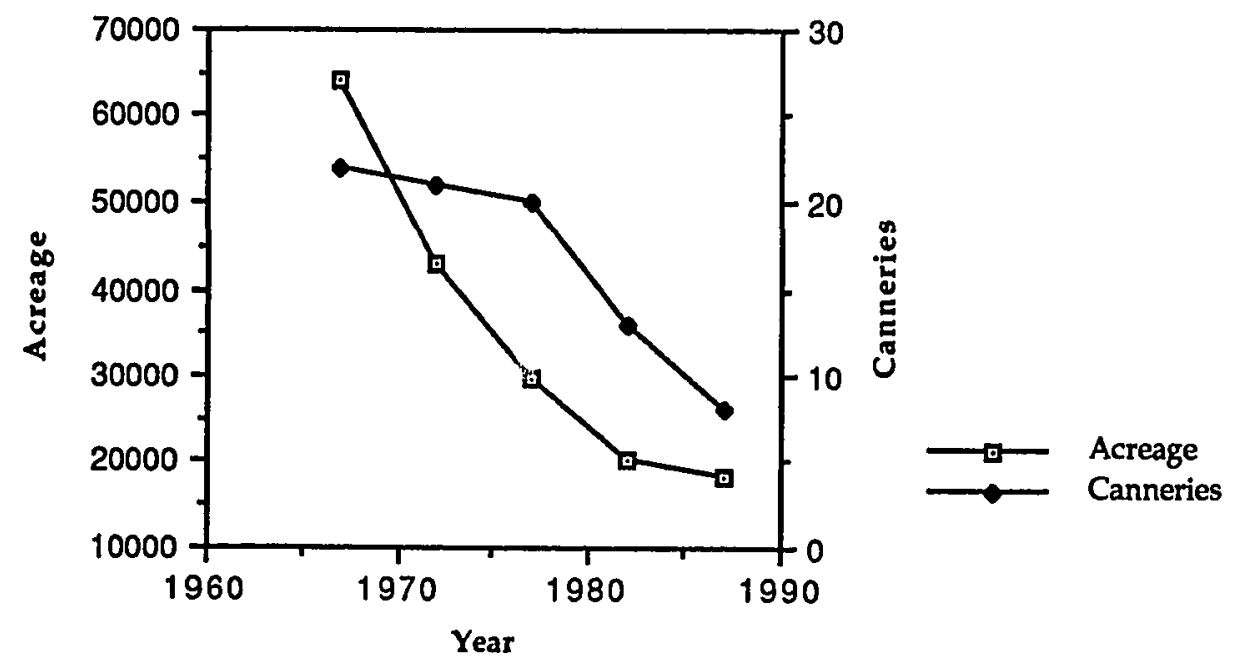

Figure 7.1 Trends in fruit and vegetable acreage and canneries. 
The number of acres devoted to the production of fruit and vegetables in Santa Clara County has declined dramatically. In 1967, 64,031 acres were devoted to these products, but by 1987 that number had been declined to 18,356 (Figure 7.1). The coefficient of correlation of reduced acreage to the industry's decline is very high, .80 . This indicates a positive association; as the acreage declined so did the number of canneries.

In addition to the reduction in agricultural acreage, the County has also dramatically declined in overall agricultural importance. The greatest changes can be seen in apple, apricot, peach, pear, plum and prune, and tomato production (Figures 7.2-7.8).

Since 1969, there has been a shift in fruit production to the Central Valley. This area has experienced substantial growth in apple, apricot, cherry, pear, plum and prune, and tomato production. Santa Clara County has, at best, only maintained its shrinking share of the total. The decline is most dramatic in apricot, cherry, plum and prune, and tomato production. The Central Valley has become the state's leading producer of fruit and vegetables. The most significant increases occurred in Stanislaus, San Joaquin and Fresno Counties.

Labor

Townroe (1969) specifically cites labor militancy as an external pressure for relocation. Indeed, the coefficient of correlation for both the number and cost per employee is very high, although since 1967, only two work stoppages are attributable to labor unrest.

The Census of Manufacturers withheld values for 1987 because of disclosure considerations. The correlation coefficients were derived using 


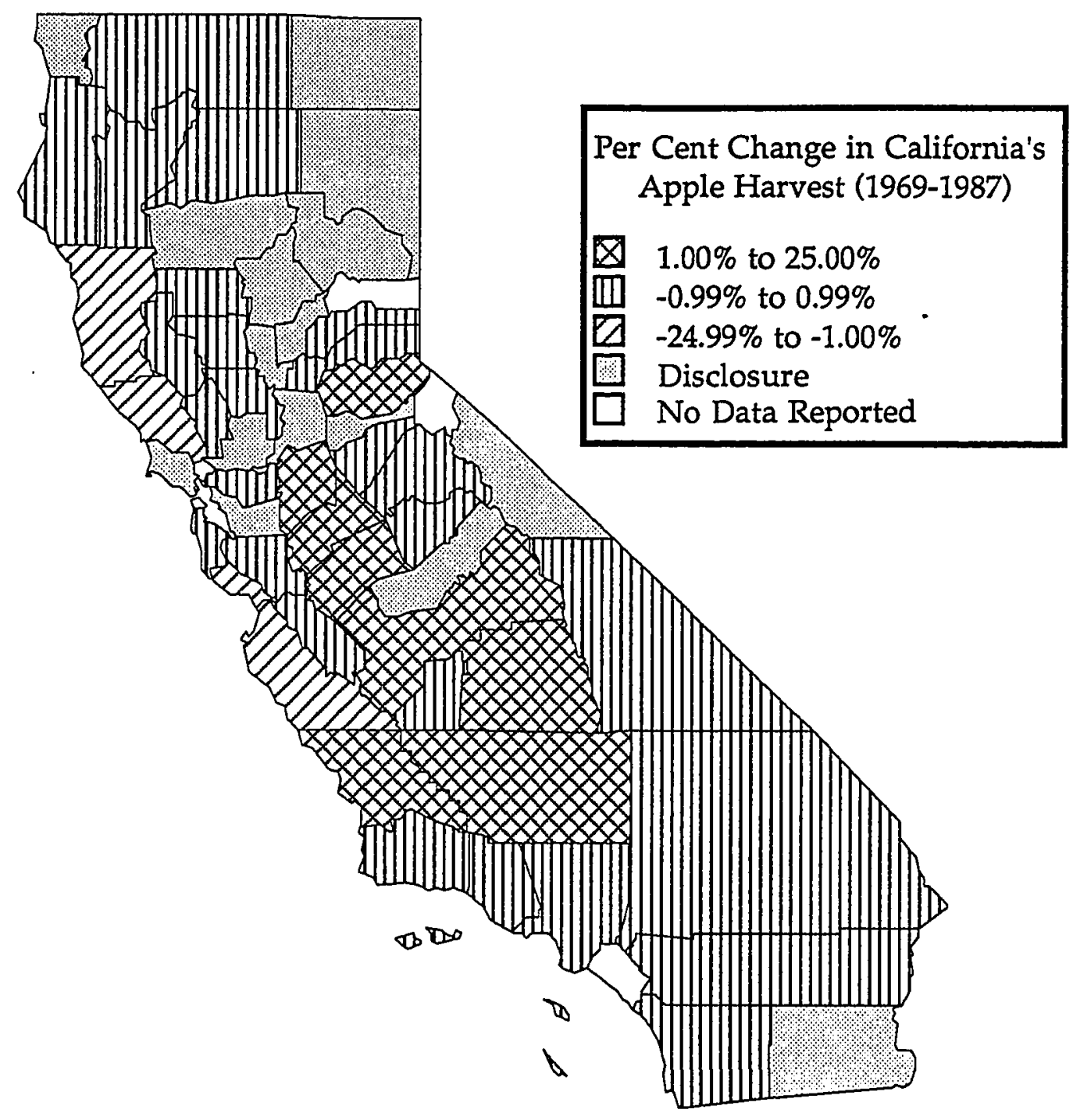

Figure 7.2 Changes in apple production. Patterns depict change in each county's contribution to California's total production. 


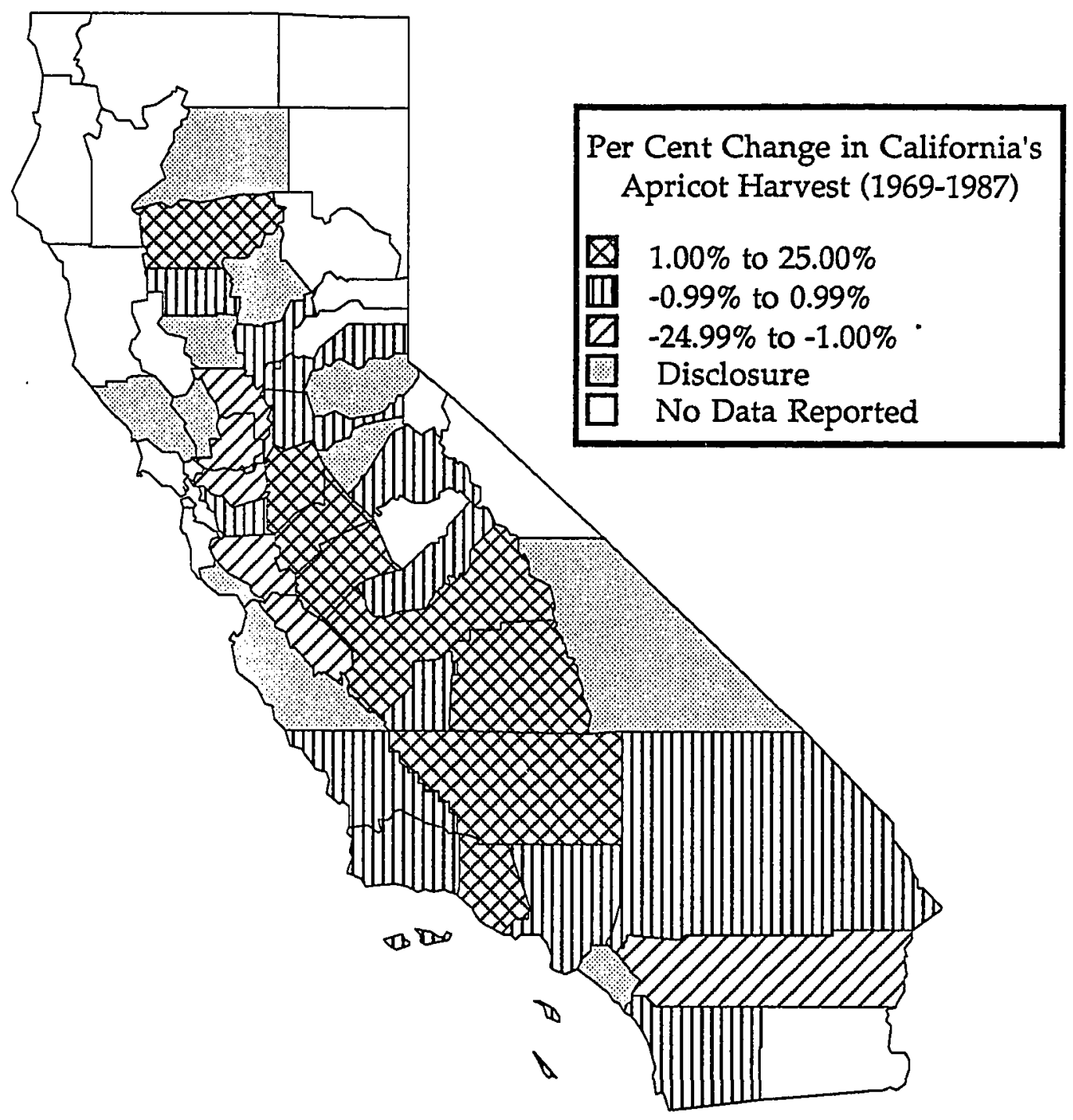

Figure 7.3 Changes in apricot production. Patterns depict change in each county's contribution to California's total production. 


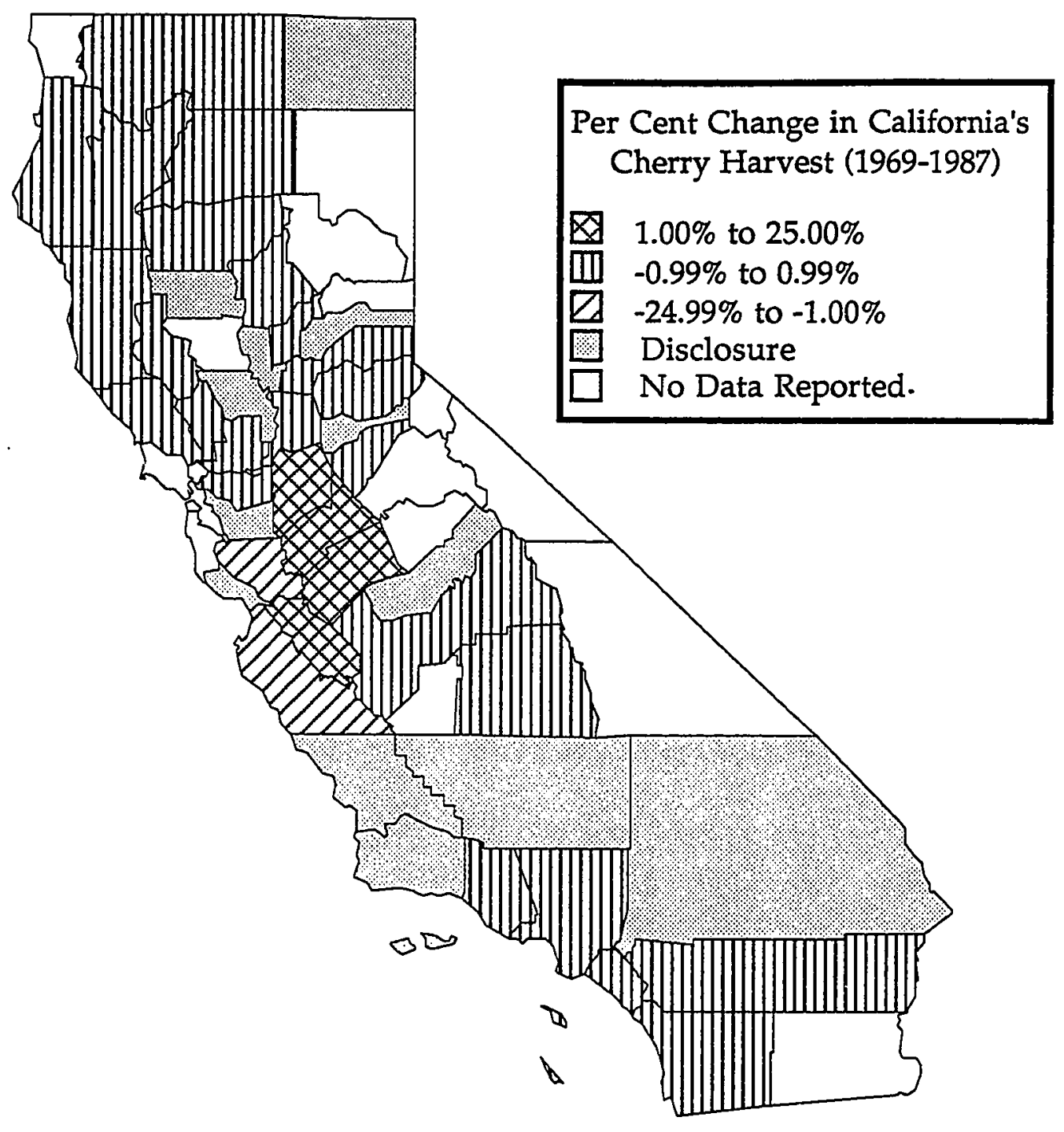

Figure 7.4 Changes in cherry production. Patterns depict change in each county's contribution to California's total production. 


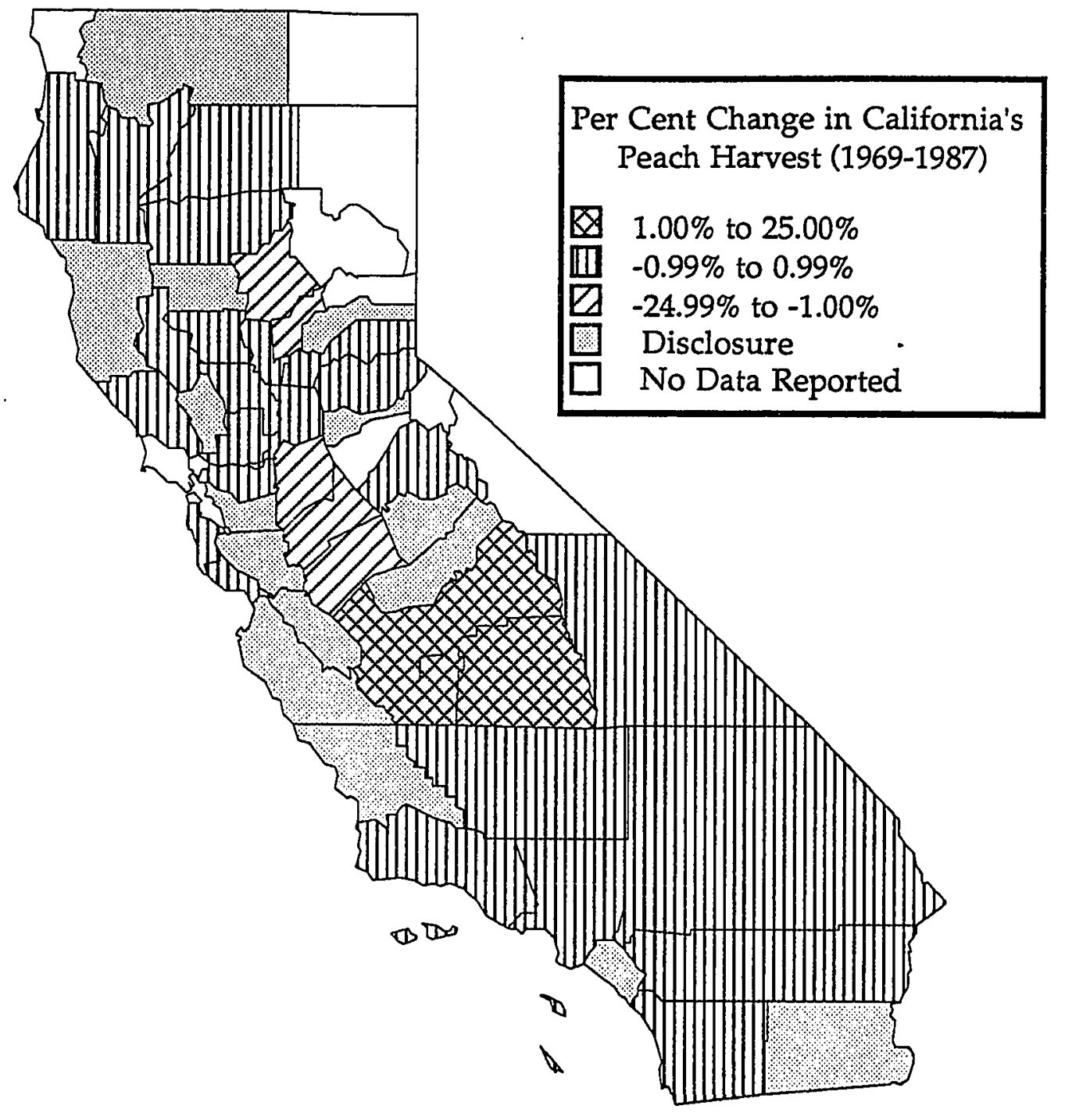

Figure 7.5 Changes in peach production. Patterns depict change in each county's contribution to California's total production. 


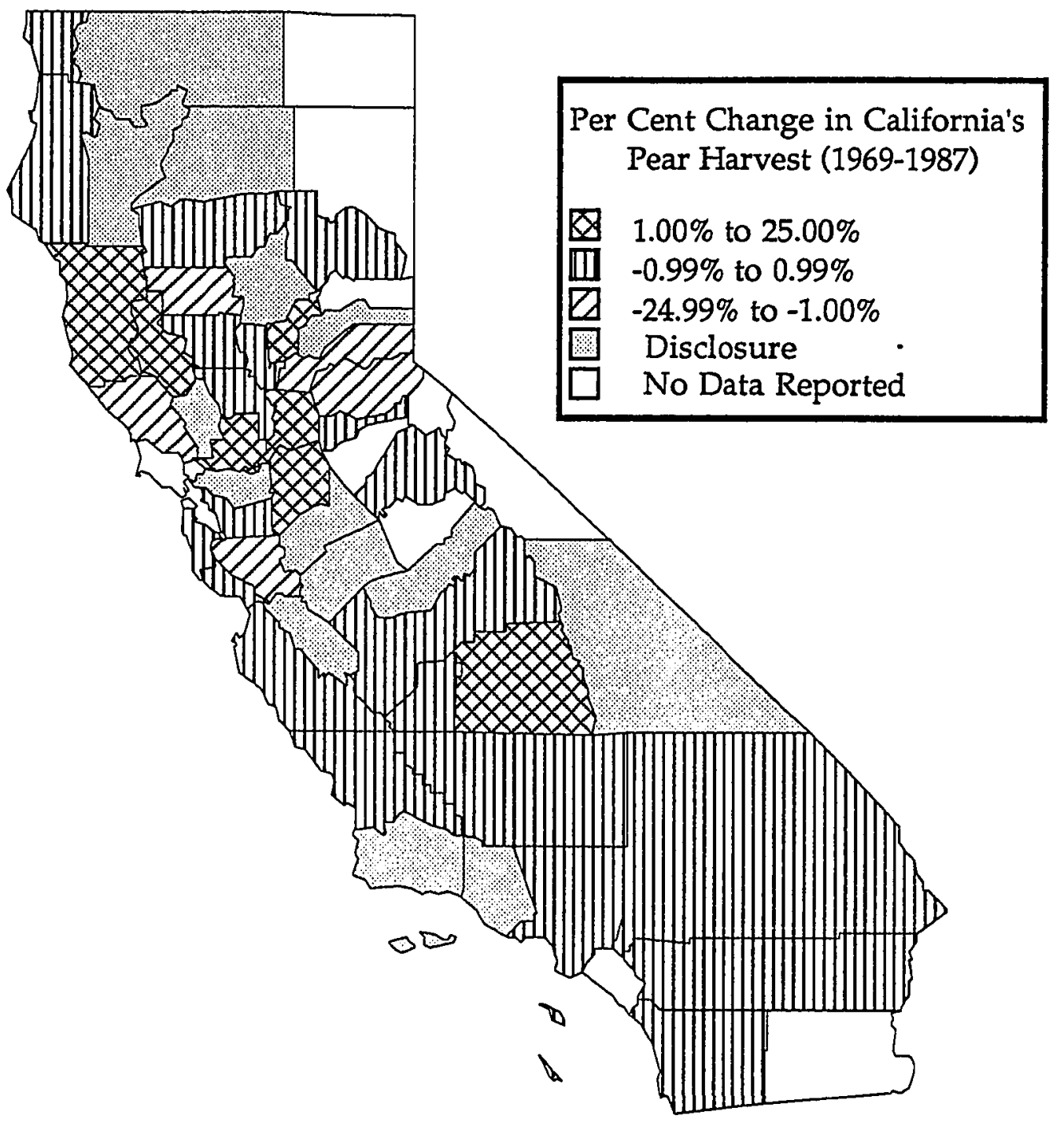

Figure 7.6 Changes in pear production. Patterns depict change in each county's contribution to California's total production. 


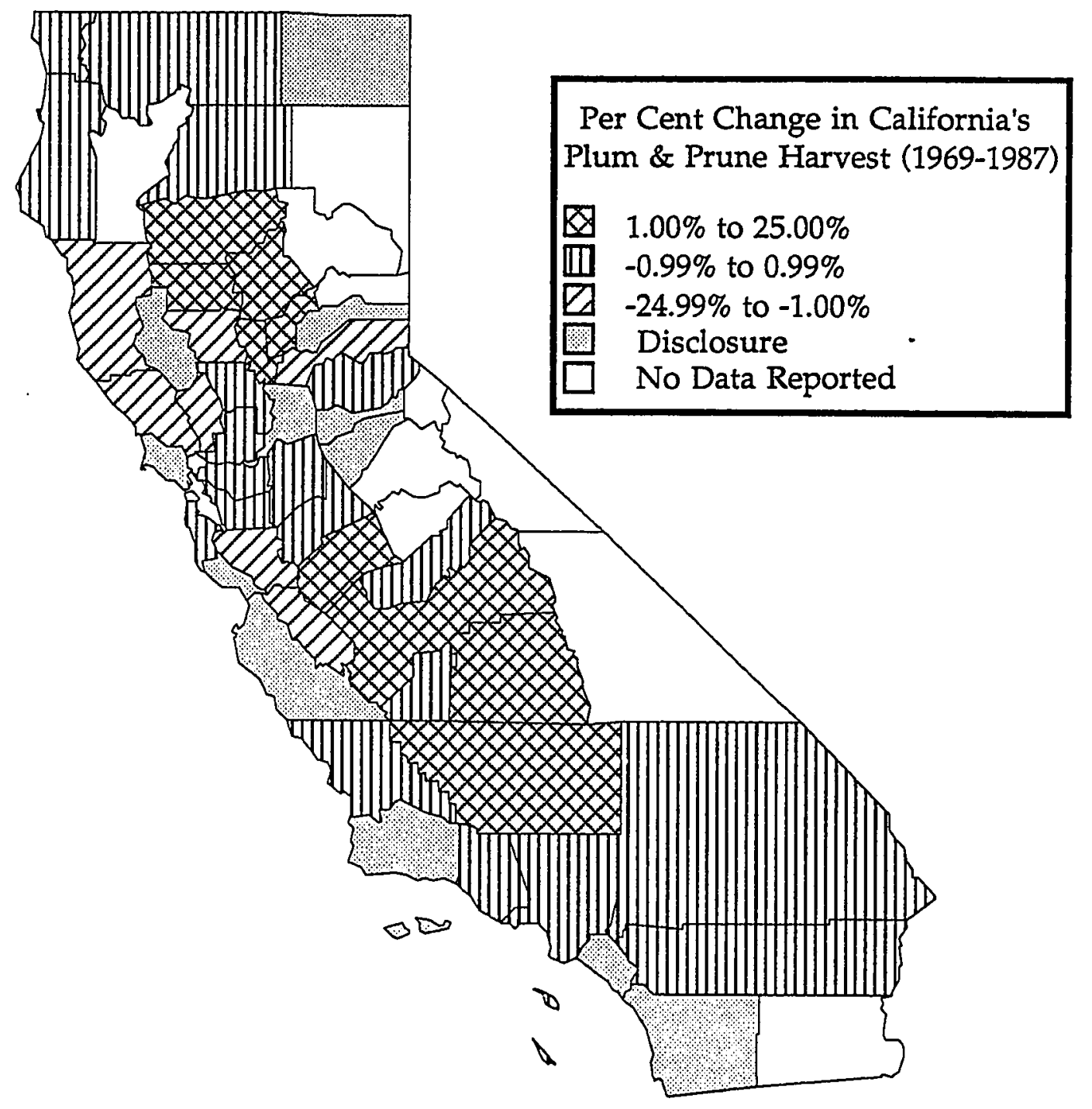

Figure 7.7 Changes in plum and prune production. Patterns depict change in each county's contribution to California's total production. 


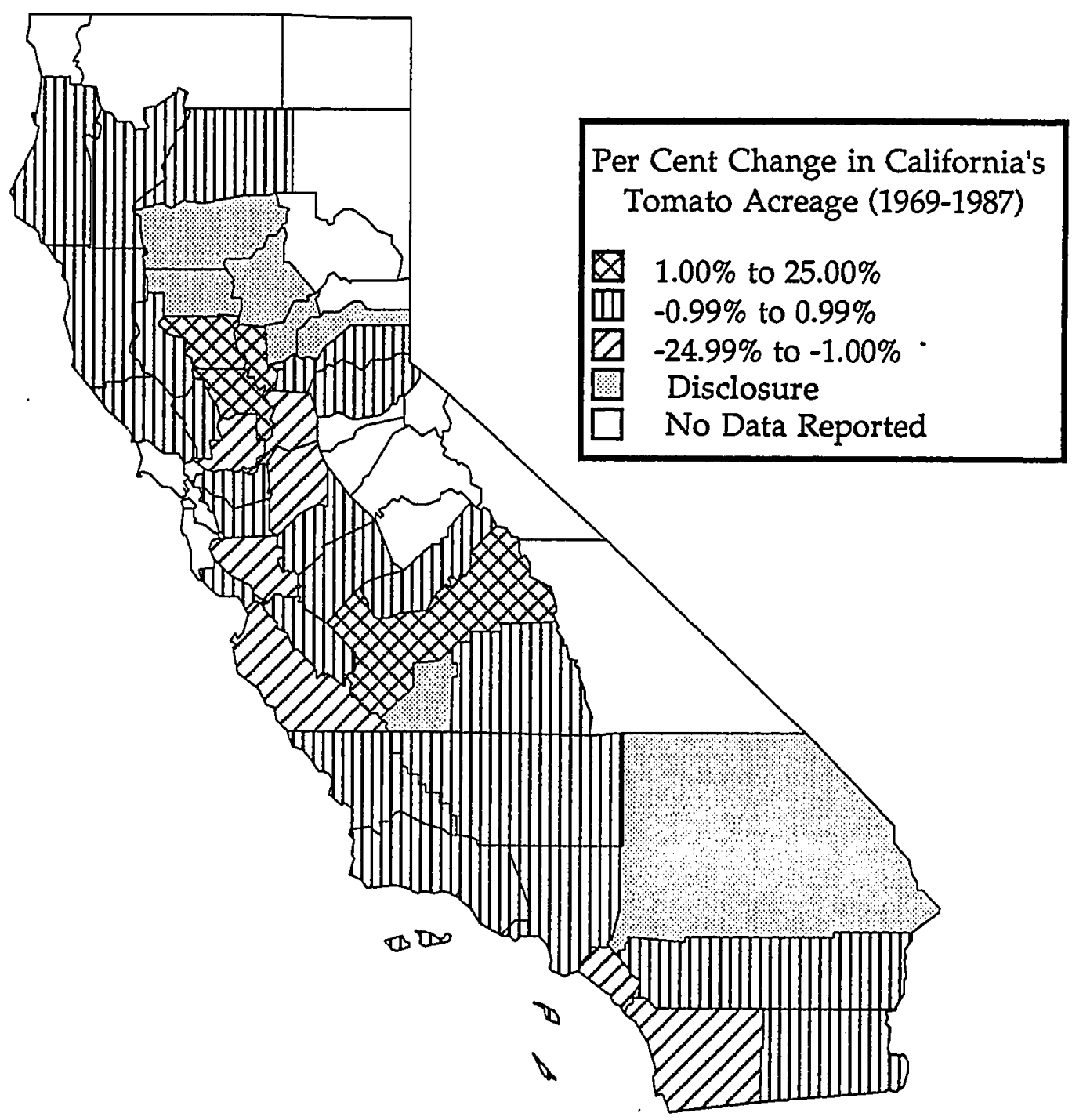

Figure 7.8 Changes in tomato acreage. Patterns depict change in each county's contribution to California's total production. 
data from 1967-1982. The coefficient of correlation is .98 for total employment. This is consistent with a declining industry. As the number of canneries decreases so should the number of employees. The coefficient of correlation for the cost per employee is -.95 (Figure 7.9). This demonstrates that as the cost per employee rises the number of canneries declines.

The cannery workers of the Santa Clara Valley have been organized in one form or another since 1931. The cannery workers have been affiliated with the International Brotherhood of the Teamsters Cannery Workers' Warehouseman-Food Processors-Drivers and Helpers Union Local 679 since 1945.

\begin{tabular}{|l|r|r|r|}
\hline \multicolumn{1}{|c|}{ Year } & \# Canneries & Employment & Cost /Employee \\
\hline 1967 & 22 & 5200 & $\$ 6000$ \\
\hline 1972 & 21 & 4700 & 7617 \\
\hline 1977 & 20 & 4600 & 12760 \\
\hline 1982 & 13 & 3400 & 19794 \\
\hline 1987 & 8 & $\mathrm{D}$ & $\mathrm{D}$ \\
\hline Correlation & & .98 & -.95 \\
\hline
\end{tabular}

Figure 7.9 Correlation coefficients for total employment and cost.

Labor contracts are negotiated every three years. Since 1967 only two work stoppages have been attributed to labor militancy. The first, in 1973, lasted only three days. The second in 1976 was somewhat more severe, effectively immobilizing the industry for eleven days. These two disputes resulted in a modest gain in the hourly wage rate.

The majority of labor unrest has come from within the union but was directed toward the union leadership, not the industry. During this time span (1967-1987), the majority of cannery workers were Mexican American. 
In 1969 a group of union members established the Mexican American Workers Educational Committee (later called the Cannery Workers Committee). The members met to discuss working conditions and to develop methods to better the interests of Mexican as well as seasonal workers. Their goal was to educate cannery workers. One of their first battles was an effort to get the union to provide copies of the labor contract in Spanish.

The committee found change difficult to attain due to the hierarchical structure of the union. Elections are a good example. Prior to 1978, all union elections were held in the winter. To qualify as a candidate, workers had to pay dues for twenty four consecutive months and attend at least half of the union meetings (Zavella, 1987, p. 63). This effectively eliminated seasonal workers, who were largely Mexican American, from participating.

The tensions within the union reached their peak during the 1970's. In order to initiate change, the committee tried petitions, legal challenges, and eventually formulated a slate of candidates to pursue positions within the union. In the early part of the decade, the committee filed a lawsuit charging Local 679 and seven canneries with discrimination ("Reform Faction Seeks," 1975). The committee also filed a complaint with the National Labor Relations Board for unfair labor practices (Calvert, 1975). In response to a complaint filed by the committee, the International President of the Teamsters, Frank Fitzsimmons, ordered balloting moved up to the peak of the cannery production period (Calvert, 1975).

In 1978, the Cannery Workers Service Center was established in San Jose with donations from the Catholic Church. This center provided services and advocacy for cannery workers. Services included classes in shop-steward 
training, a newsletter, and legal counseling, as well as referrals to social services. This center succeeded in getting the union to provide copies of the labor agreement in Spanish, something the Cannery Workers Committee had fought for for years.

\section{Waste Disposal and Government Policy}

The canning industry has been severely affected by both national and local government policy. Changes in policy have had a direct relation to changes in the cost of waste disposal and treatment.

In 1972, the Federal Water Pollution Control Act Amendments (FWPCA) became law. The goal was to eliminate all pollutants discharged into the nation's waterways by 1985 . The FWPCA applied to both the federal and state level.

These amendments required all local municipalities to establish secondary treatment facilities by 1977. At the time, most sewage systems had only primary facilities, designed to remove both organic and inorganic solids by the process of sedimentation. Secondary facilities remove both dissolved and suspended solids from wastewater. This is done using biological treatments.

The Amendment's primary mechanism for achieving its goal was a national permit system called the National Pollutant Discharge Elimination System (NPDES). Under this system, municipal dischargers must obtain a permit which sets specific limits on the discharge of pollutants to 'virtually any surface water of the United States' (Olson \& Lyons, 1979, p. 517).

Prior to regulation, canneries pumped their wastes directly into the bay. During the 1960 's, pollution legislation was enacted. Canners began to screen 
their waste water. The waste was collected and disposed of in County dump sites. In 1969, six of the ten sites were closed. Local canners organized and formed the Cooperative for Environmental Improvement, Inc. This was a one million dollar venture that disked thousands of tons of fruit and vegetable pulp into a grassland near the Santa Clara-San Benito County lines (Harris, 1971).

In the early 1970's, the San Jose sewage treatment facility was required to implement an advanced third stage facility, one which would remove colloidal material. Advanced waste treatments can be designed to remove specific pollutants and increase the quality of waste water. San Jose's Public Works Director, Anthony R. Turturici expected the new treatment facility's output to be nearly pure enough to drink (Acuna, 1976).

The addition of the third stage facility dramatically increased sewage costs to canners. In 1976, cannery sewage taxes were increased 250 per cent from the previous year ("Canners Sewer Fuss," 1976). Later the increase was reduced by thirteen per cent (Gruber, 1976a). During this time canners and labor leaders voiced their objections and predicted the County's industry decline ("Canners Sewer Fuss," 1976; "S.J. Workers Fear Job," 1976; "Cannery Official Ask Delay," 1976; "S.J. Increases Fees," 1976).

Edwin L. Mitchell, president of the Santa Clara County Canners Association, argued against the tax increases. He demonstrated that canners would be paying $31 \%$ of the interest costs of the plant, but would be producing only $13.5 \%$ of the sewage (Gruber, 1976b). The reaction from local officials was unsympathetic. Mayor Janet Gray Hayes was quoted as saying, "It's very unlikely they're going to move" as a result of the proposed rate hikes ("S.J. 
Workers Fear Job," 1976). In the following six years, the County lost seven canneries.

A proposal was made by the City Council to alleviate the burden on local canneries. They proposed a system of on-site sewage treatment for the industry. The idea was to treat the majority of wastes at the cannery, thus avoiding most sewer fees. In 1979, the state of California undertook a waste water reclamation feasibility study for the San Jose Area. Based on location, availability of a large plot of land, and landscape irrigation, the study concluded it was not feasible to treat wastes at the cannery. It further stated that the use of reclaimed water from canneries was impossible. The reasons were as follows: the cost of the reclaimed water was prohibitive, reclaimed water could not be used for industrial purposes nor could it be used for recreational purposes due to quality considerations (California Department of Water Resources, 1979).

Since the late 1970's, the basic charge per hundred cubic feet of sewage discharged has increased 365 per cent. The coefficient of correlation to the

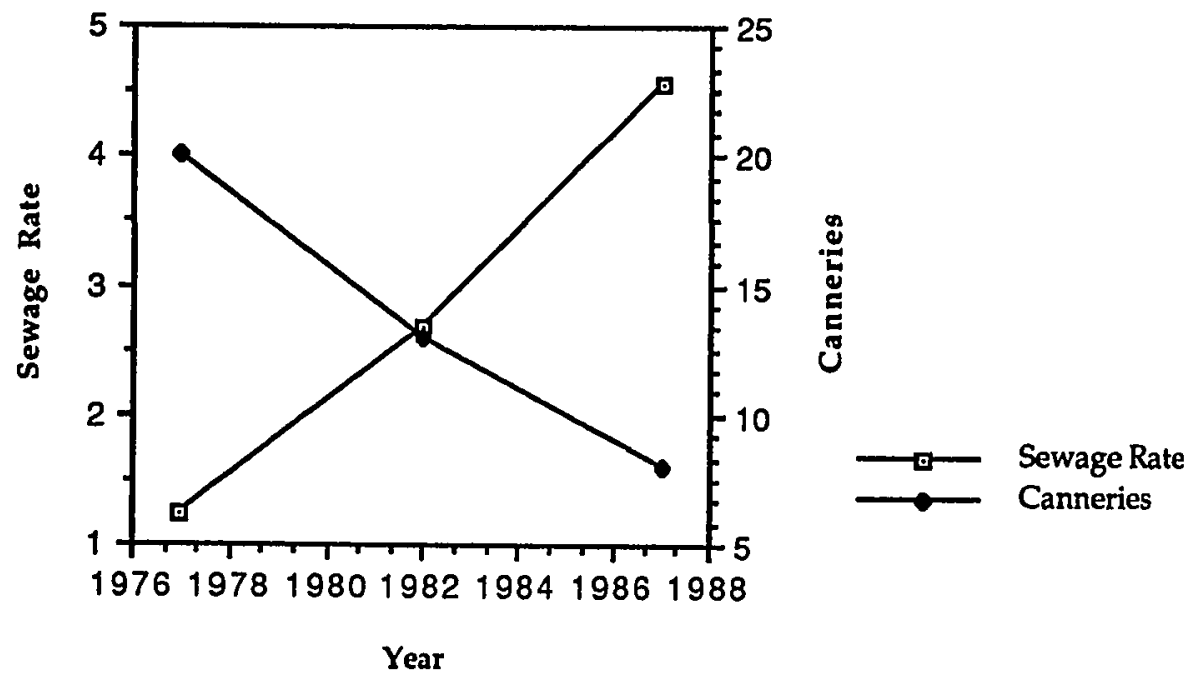

Figure 7.10 Trends in costs for sewage discharge and canneries. 
number of canneries is -.98 (Figure 7.10). This indicates a strong negative correlation. As the sewage rates increased, the number of canneries decreased.

\section{Large Cooperatives and Corporations}

Initially the canning industry was made up of small specialized organizations. Many were family run businesses. Firm contractual agreements were made with farmers before the seeds were planted (Alexander, 1963, p. 296). Processors determined price and product.

The cooperatives destroyed this process. They were run by the growers. Farmers, in effect, owned the processing facilities and determined what and how much would be processed. The financing was guaranteed by the growers, not the cannery. The change in financial practice severely altered the industry's stability state wide.

The California Packing Corporation was founded in 1916. The dominant cooperatives were the California Canners and Growers ( $\mathrm{Cal} \mathrm{Can}$ ) and Tri-Valley. Cal Can was established in the 1950's and Tri-Valley shortly thereafter. California Packing Corporation processes under the Del Monte label. Cal Can used the Libby label and Tri-Valley packed under the S\&W and Glorietta Foods brands.

As the cooperatives grew so did the financial debt (Perkins, 1991). By the late 1960's and early 1970's this crisis reached its peak. Many processors were selling products at a loss. As banks began clamping down, the industry as a whole was in financial trouble.

In addition to the internal problems, the industry was hard hit by national economic trends and consumer preferences. In the 1970's, rampant 
inflation led to Presidential intervention. President Nixon proposed and fought for an economic package which froze all processed food prices yet allowed prices for raw materials to rise to whatever the market would allow (Braznell, 1982, p. 155). In the late 1970's and early 1980's, consumers' food preferences altered. Consumption of canned goods plummeted (Figure 7.11).

\section{U.S. Fruit and Vegetable Consumption}

(Processed Weight)

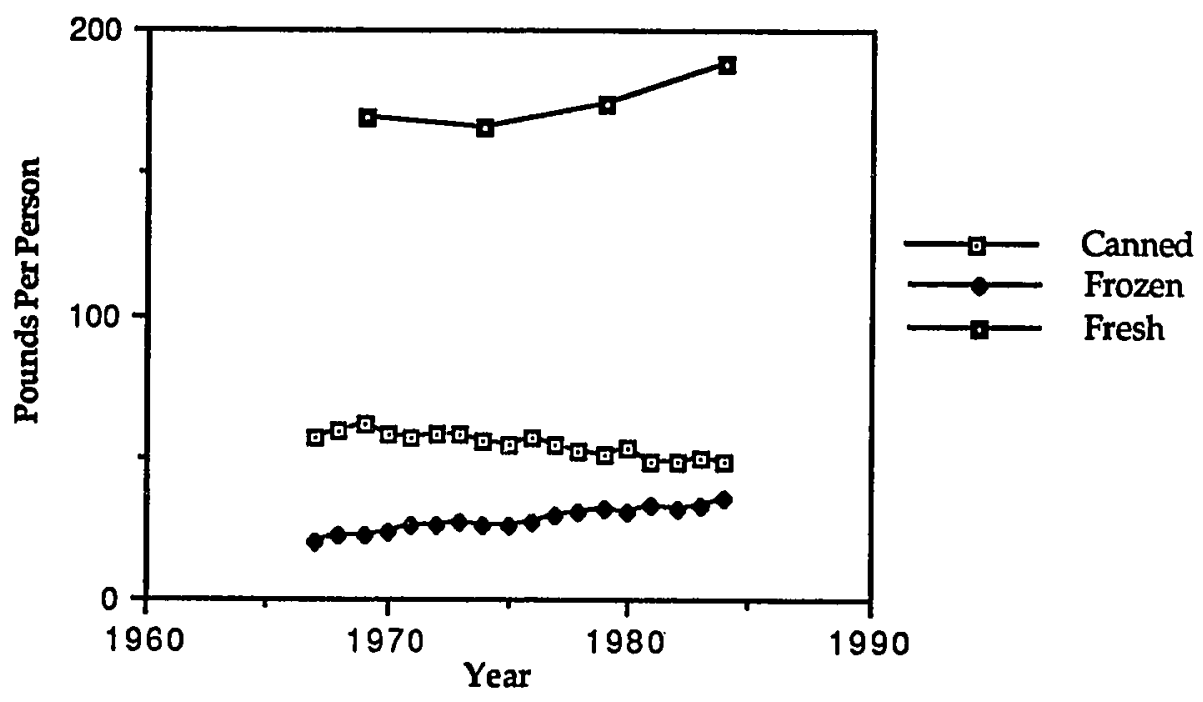

Figure 7.11 U.S. civilian fruit and vegetable consumption.

In order to survive, the large cooperatives attempted to consolidate. In 1969, Tri-Valley closed its two plants in San Jose and transferred its operation to its new modern Modesto facility. Cal Can closed two of its five plants in the County, one in Sunnyvale and the others in San Jose. The equipment from these facilities was also transferred to the Central Valley.

In 1979, California Packing Corporation and the Del Monte label were sold to R.J. Reynolds. In 1986, it was sold again to Merrill Lynch. In 1983, Cal Can, the nations second largest producer of canned goods, filed for bankruptcy 
(Shephard, 1983). Tri-Valley acquired the bulk of Cal Can's assets and has since prospered. It is one of the few large organizations run by people familiar with the canning industry. The other large organizations are administered by managers of diversified corporations.

\begin{tabular}{|c|c|c|}
\hline & Independents & Large Organizations \\
\hline 1967 & 10 & 12 \\
\hline 1972 & 8 & 13 \\
\hline 1977 & 8 & 12 \\
\hline 1982 & 5 & 8 \\
\hline 1987 & 5 & 3 \\
\hline
\end{tabular}

Figure 7.12 Santa Clara County cannery ownership.

Of the eight canneries left in 1987 only three were affiliated with cooperatives or corporations (Figure 7.12). The others were small independently run canning operations.

\section{Discussion}

The data presented indicate strong associations with the canning industry's decline. The changes in the structure of the industry as well as the impact of local government policy had a profound effect. Labor militancy was a less substantial factor. The labor union was essentially powerless. Disagreements among its members, coupled with the financial instability of the industry, left the labor organization with few options. The improvements at the sewage treatment plant substantially raised operation costs for canneries. 
The most ambiguous results involve the changes in agricultural production. Between 1967 and 1987 the County lost over 40,000 acres of fruit and vegetable acreage (Figure 7.13). Although this reduction is substantial, it is insignificant when compared to the loss of acreage between 1930 and 1967 (Figure 5.2:, page 32).

The loss of the canning industry has had no severe effects on the County. The use of land previously occupied by canneries has, for the most

\begin{tabular}{|r|r|r|r|}
\hline Year & Fruit Acreage & $\begin{array}{c}\text { Vegetable } \\
\text { Acreage }\end{array}$ & \multicolumn{1}{l|}{ Total } \\
\hline 1930 & 186964 & 26590 & 213554 \\
\hline 1941 & 101328 & 20880 & 122208 \\
\hline 1950 & 86105 & 26277 & 112382 \\
\hline 1960 & 64452 & 14220 & 78672 \\
\hline 1970 & 38614 & 15615 & 54229 \\
\hline 1980 & 11150 & 13624 & 24774 \\
\hline 1987 & 8286 & 12355 & 20641 \\
\hline
\end{tabular}

Figure 7.13 Fruit and vegetable acreage totals. Source: Santa Clara County Agricultural Crop Reports.

part, remained industrial. Multi-storied office buildings have also been built where canneries once stood. A couple of the canneries in San Jose have simply been abandoned. The most unusual conversion has occurred in Cupertino. The cities only cannery has been converted into a type of museum. The buildings have been identified by function, unfortunately the area is inaccessible.

In 1987, the principal producer of canned fruits and vegetables was San Joaquin County (Figure 7.14). This area produces all types of canned fruits 


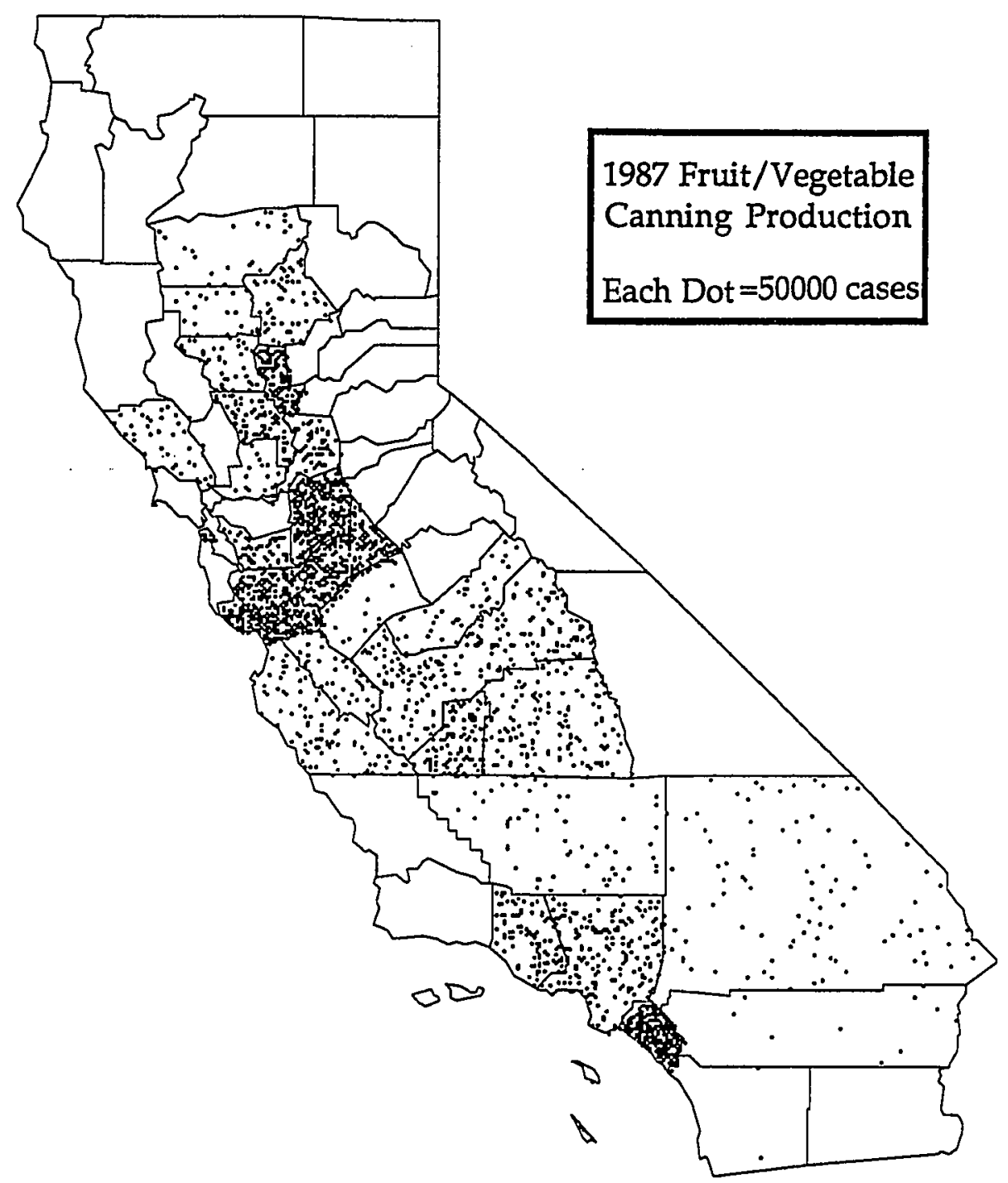

Figure 7.141987 canned fruit and vegetable production. 
The central portion of the state produces the bulk of the industry's output. The production in Southern California is almost entirely attributable to the production of fruit drinks, jams or jellies. These products account for $85 \%$ that areas total canning output. 


\section{CONCLUSIONS}

The canning industry is not an insular operation. Rather, it is part of a larger whole. The decline of the industry cannot be explained by simply looking at one or two factors.

The correlation coefficients for labor, agricultural production and sewage rates were all very high. This does not relate cause and effect; it merely expresses a quantitative measurement of association. Nevertheless, by examining the ancillary data it can be said that they influenced the decline of the industry.

Theoretically, Townroe finds internal factors to be the most influential. This study is consistent with that approach. Changes in the structure of the industry on the national level proved to be disastrous for Santa Clara County. The advent of large cooperatives and corporations almost destroyed the industry. External pressures also contributed.

Labor militancy, during the period of study, was not found to exist in the County. The struggles encountered were within the union. They were directed against the union leadership, not the managers of the industry.

The most common explanation is that the industry moved as a result of agricultural decline. The production of fruit and vegetables in this County has substantially declined since 1940. If this were the primary cause of the canning industry's decline, the industry would have disappeared long ago.

The move toward large cooperatives and corporations was the primary reason the industry left the County. The most dramatic decline occurred during the late 1970's and early 1980's. This is when the sewer fees were 
imposed. More significantly, it was when the industry was undergoing significant hardships.

In the 1960's and early 1970's competition from grower owned processor cooperatives became very serious. The overall demand for processed food was weak. New technology had brought new areas into production. Inventories became heavy. Large carry over inventories were a problem and this further weakened the market.

The decision to close down the less profitable installations was made in an effort to streamline the industry. Most of the raw materials were obtained from outside the County, primarily from the Central Valley. The rising sewer costs and lack of support from local government made this area less attractive.

The Central Valley became the location of choice. There, treated waste water can be used to irrigate crops. Large processors have taken the initiative in reducing solid waste. Organic wastes are recycled. Processing wastes such as peach pits, and other organic components are utilized as fuel for generating steam for processing.

The future of the canning industry in Santa Clara County is bleak. In 1987 , only eight canneries were left in the County. Last year, two independent operations decided to leave. The F.G. Wool Packing Company closed down its operation and Gangi Bros. Packing Company announced its move to Modesto. The future for the remaining operations is short. Sewage costs continue to rise. This along with the increased cost of raw material will eventually force the small canners to shut down. 
The majority of large organizations have already relocated. Despite this fact, Del Monte still operates a large facility in San Jose. The cost of maintaining it far from the bulk of the industry, however, will eventually force it to shut down.

The corporate facility in Gilroy has the best location. Despite sewage disposal restrictions, the availability of fruits and vegetables in the southern portion of the County, the proximity to the Central Valley, California's principal agricultural region, gives the canneries in Gilroy a better chance of survival.

California is the principal producer of canned fruits and vegetables. The bulk of production is done in the Central Valley. The factors affecting the decline of the canning industry in Santa Clara County may eventually influence canneries in the rest of the state. If the Sacramento and San Joaquin Valleys experience sustained population growth, large amounts of agricultural land would be taken out of production. This coupled with any of the following -- a shift in local government support, labor difficulties, waste water disposal or difficulty in obtaining water -- may force canneries to relocate to a more favorable environment.

The industry might consider the Pacific Northwest, the Midwest, and parts of the South as potential areas for relocation. The Midwest, specifically, Illinois, Indiana, Michigan and Minnesota are significant producers of canned vegetables. Oregon, Washington, Georgia and South Carolina are important producers of canned fruit. The fruit regions have the greatest potential for growth. Choosing a more favorable location, outside California, would require a more intensive study of these regions. 


\section{REFERENCES}

Acuna, A. (1976, January 7). 1500 protest sewage change. San Jose Mercury p. 1B.

Alexander, J. (1963). Economic Geography. Englewood Cliffs: Prentice Hall, Inc.

Almanac of Canning Freezing Preserving Industries. (1967). Westminster, MD: Edward Judge and Son Publishing Company Inc.

Almanac of Canning Freezing Preserving Industries. (1977). Westminster, MD: Edward Judge and Son Publishing Company Inc.

Almanac of Canning Freezing Preserving Industries. (1987). Westminster, MD: Edward Judge and Son Publishing Company Inc.

Almanac of Canning Freezing Preserving Industries. (1989). Westminster, MD: Edward Judge and Son Publishing Company Inc.

Alonso, W. (1967). A reformulation of classical location theory and its relation to rent theory. Papers, Regional Science Association, 19 23-44.

Arbuckle, C. (1986). History of San Jose. San Jose, CA: Memorabilia of San Jose.

Arnold, F. (1976). A history of struffle: organizing cannery workers in the Santa Clara Valley. Southwest Economy and Society 2, 26-38.

Auty, R.M. (1975). Scale economies and plant vintage, toward a factory classification. Economic Geography 51, 150-162.

Beckett, J. (1986, September 25). Decline of California's canners. San Francisco Chronicle pp. C1, C5.

Bowman, N. (1956, August 7). Harvest reaches its peak. San Jose Mercury, p. 15.

Braznell, W. (1982). California's Finest, The History of Del Monte Corporation and the Del Monte Brand. San Francisco: Del Monte Corporation. 
Broek, J.M. (1932). The Santa Clara Valley: A Study in Landscape Changes.

Utrecht, The Netherlands: N.V.A. Oosthoek's Uitgevers.

California canners to halt operations, transfer its plants. (1983, June 23). The Wall Street Journal, p. 14.

California Department of Water Resources Central District. (1979). Cannery Waste Water Reclamation Study: San Jose Area. Sacramento, CA:

Department of Water Resources Central District.

Calvert, C. (1975, September 29). Canners fight for power. San Jose News, p. 17.

Calvert, C. \& Gathright A. (1984, January 20). Making way for high tech in S.J.. San Jose Mercury pp. 1A, 16A.

Canners, city joined in sewer fee fuss. (1976, January 3). San Jose News, p. 23.

Cannery union lashed over sewer protest. (1976, January 17). San Jose Mercury p. 16A.

Cannery workers, officials ask sewer tax action delay. (1976, January 8). $\underline{\text { San }}$ lose News, p. 10.

Cannery workers seek public vote on sewer project. (1976, January 13). San Iose News, p. 11.

Castillo, E. (1980, August, 24). Canning industry still fruitful here. San Jose Mercury News, pp. 1C, 2C.

Chapman, K., \& Walker, D. (1987). Industrial Location: principles, and policies. New York: Basil Blackwell.

Chisholm, M. (1967). General systems theory and geography. Institute of British Geographers, Transactions, $\underline{42}$, 45-52.

Claus, R.J. (1966). The Fruit and Vegetable Canning Industry in the Santa Clara Valley. Unpublished master's thesis, San Jose State University, San Jose, CA.

Claus, R.J., and Dalichow F. (1971). California: center of the U.S. fruit and vegetable canning industry. Zeitschrift fur Wirtschaftsgeographie, 15 165-171. 
Del Monte firmly rooted in county, chairman says. (1974, October 16). San Iose News, p. 4.

Directory of Canning Freezing Preserving Industries: 1966-67. (1966). Westminster, MD: Edward Judge and Son Publishing Company Inc.

Directory of Canning Freezing Preserving Industries: 1986-87. (1986). Westminster, MD: Edward Judge and Son Publishing Company Inc.

Fay, J., Lipow, A., \& Fay, S.W. (1987). California Almanac (3rd ed.). Novato, CA: Presidio Press and Pacific Data Resources.

Felton, E.L. (1965). California's Many Climates. Palo Alto, CA: Pacific Book Publishers.

Foster, M.I. (1972). Is the south still a backward region, and why? American Economic Review, Proceedings. 62, 195-203.

Fruit processing. (Special Edition, 1951, June 17). San Jose Mercury (Pages of the Past), p. 127.

Goldston, L. (1982, December 18). S.J. will lose another cannery and 205 jobs. San Jose Mercury News, p. 1B.

Green, M.B. \& Cromley, R.G. (1982). The horizontal merger: Its motives and spatial employment impacts. Economic Geography 58, 358-370.

Green, J. H., \& Kramer, A., (Eds.) (1979). Food Processing Waste Management. Westport, CT: AVI Publishing Company Inc.

Greenhut, M. (1956). Plant Location in Theory and Practice. Chapel Hill, NC: University of North Carolina Press.

Griffin, P.F., \& Chatham, R.L. (1958). Urban impact on agriculture in Santa Clara County, California. Annals of the Association of American Geographers, 55, 465-91.

Gruber, S. (1976a, February 26). Cannery sewer fee cut sought. San Jose News, p. 16.

--.-. (1976b, March 3). Huge sewer fee increase approved for canneries. $\underline{\text { San }}$ lose News, p. 24. 
Hamilton, F.E. I., (Ed.) (1974a). Spatial Perspectives on Industrial Organization and Decision Making. New York: John Wiley and Sons.

--.--. (1974b). A view of spatial behavior, industrial organization and decision making. In F.E.I Hamilton (Ed.), Spatial Perspectives on Industrial Organization and Decision Making. (pp. 3-46.) New York: John Wiley and Sons.

-.--. (1978). Industrial Change. New York: Longman.

Hamilton, F.E. I., \& Linge G.J.R., (Eds.) (1979). Spatial Analysis, Industry and the Industrial Environment. Volume 1: Industrial Systems. New York: John Wiley and Sons.

----. (1983). Spatial Analysis, Industry and the Industrial Environment. Volume 3: Regional Economies and Industrial Systems. New York: John Wiley and Sons.

Harris, T. (1971, October 11). Canneries gamble $\$ 1$ million on waste disposal program. San Jose Mercury p. 21.

Hartshorne, R. (1927). Location as a factor of geography. Annals of the Association of American Geographers, 17, 92-99.

Hawkins, B. (1969, April 22). Canning pioneer Gray watches industry decline. San lose News, p. 55.

Hayter, R. (1978). Locational decision-making in a resource based manufacturing sector, case studies from the pulp and paper industry of British Columbia. Professional Geographer, 30 240-249.

Hernandez, M. (1977, August 8). Orchards long gone - valley canneries still big industry. $\underline{\text { San lose Mercury p. } 1 .}$

Hoare, A. (1981). Why they go where they go: the political imagery of industrial locations. Institute of British Geographers, Transactions, 6 , $152-175$.

-----. (1986). What do they make, where, and does it matter anymore? Geography $71,289-304$. 
Holt-Jensen, A. (1980). Geography Its History and Concepts. London: Harper and Row.

Isard, W. (1956). Location and Space Economy. Cambridge, MA: Massachusetts Institute of Technology.

Jacobson, Y. (1984). Passing Farms Enduring Values, California's Santa Clara Valley. Los Altos, CA: William Kaufman Inc.

Jones, H.R. (1973). Waste Disposal Control in the Fruit and Vegetable Industry. Park Ridge, NJ: Noyes Data Corporation.

Juarez, L. (1975, September 21). Cannery job opportunities shrink with

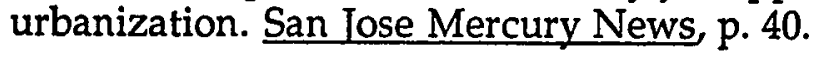

-..-. (1975, September 28). Canneries busy in S.J. San Jose Mercury News, p. 25.

Keeble, D. (1968). Industrial decentralization and the metropolis: the northwest London case. Institute of British Geographers, Transactions, $\underline{44}$, 154.

-----. (1981). Manufacturing dispersion and government policy in a declining industrial system: the United Kingdom case 1971-1976. In J. Rees, G. Hewings \& H. Stafford (Eds.), Industrial Location and Regional Systems. (pp. 197-216). New York: Bergin Publishers.

Larimore, J. (1965, September 10). Not so peachy at the canneries. San Jose Mercury p. 1.

Lebowitz, M.A. (1976). Marx's falling rate of profit: a dialectical view. Canadian Journal of Economics, 9 , 232-254.

Lever, W.F. (1978). Company dominated labour markets: the British case. Tijdshrift voor Economische en Sociale Geografie, 69, 306-312.

----. (1985). Theory and methodology in industrial geography. In M. Pacione (Ed.), Progress in Industrial Geography. (pp. 10-39). Dover, NH: Croom Helm.

Lindsey, B. (1959, January 21 ). Fire sweeps huge cannery, $\$ 400,000$ blaze hits Libby plant. San Jose Mercury p. 1. 
Loomis, P. (1982, August 30). Cannery closing signals the end of an era in valley. San Jose News, pp. 1B, 6B.

----. (1982, November 24). At Ainsley Packing, day care got an early start. San Jose Mercury p. 2B.

Lösch, A. (1954). The Economics of Location. New Haven, CT: Yale University Press.

Luh, B.S., \& Kean, C.E. (1988). Canning of vegetables. In B. S. Luh \& J. G. Woodroof (Eds.), Commercial Vegetable Processing. (pp. 195-285). New York: Van Nostrand Reinhold.

Luh, B.S., Kean, C.E., \& Woodroof, J.G. (1986). Canning of fruits. In B. S. Luh \& J. G. Woodroof (Eds.), Commercial Fruit Processing. (pp. 163-261). Westport, CT: AVI Publishing Company Inc.

Massey, D. (1984). Spatial Divisions of Labour: social structures and the geography of production. New York: Macmillan.

Massey, D., \& Meegan R. (1978). Industrial restructuring versus the cities. Urban Studies, 15, 273-88.

---.-. (1979). The geography of industrial reorganization. Progress in Planning. 10, 155-237.

McNee, R.T. (1960). Toward a more humanistic economic geography: the geography of enterprise. Tijdshrift voor Economische en Sociale Geografie, 51, 201-206.

---. (1974). A systems approach to understanding the geographic behavior of organizations, especially large corporations. In F.E.I Hamilton (Ed.), Spatial Perspectives on Industrial Organization and Decision Making. (pp. 47-76). New York: John Wiley and Sons.

Meigs, P. (1941). Current trends in California orchards and vineyards. Economic Geography 20, 275-86.

Mercer, W.A., Rose W.W., Butler, C.E., \& Appleman, M.M. (1958). More effective product washing with less water. National Canners Association Information Letter, 1666, 2-7. 
Miller, E. W. (1977). Manufacturing: A Study of Industrial Location. University Park, PA: Pennsylvania State University Press.

Moran, K. (1983, October 3). Continental Can to cut back, modernize operation. San Jose Mercury News, pp. 1B, 4B.

North, D. J. (1974). The process of locational change in different manufacturing organizations. In F.E.I Hamilton (Ed.), Spatial Perspectives on Industrial Organization and Decision Making. (pp. 213244). New York: John Wiley and Sons.

Olson, Donald M., \& Lyons, David N. (1979). NPDES compliance monitoring. In J.H. Green and A. Kramer (Eds.), Food Processing Waste Management. (pp. 517-526). Westport, CT: AVI Publishing Company Inc.

Olson, W. (1969). Changing patterns of tomato production in California. California Geographer, 10, 15-26.

Payne, S. (1987). Santa Clara County, Harvest of Change. Northridge, CA: Windsor Publications Inc.

Perkins, J. (1991). Food Processing Consultant. Interview. 16 March 1991.

Reform faction seeks canners union control. (1975, September 30). San Jose Mercury p. 8.

San Jose Chamber of Commerce. (1986). Economic Fact Book. San Jose, CA: Author.

Santa Clara County Agriculture Department. (1966). Agricultural Crop Report. San Jose, CA: Author.

----. (1968). Agricultural Crop Report. San Jose, CA: Author

-.-.. (1972). Agricultural Crop Report. San Jose, CA: Author.

---.. (1977). Agricultural Crop Report. San Jose, CA: Author.

-.--. (1982). Agricultural Crop Report. San Jose, CA: Author.

---. (1987). Agricultural Crop Report. San Jose, CA: Author. 
Santa Clara County Planning Department. (1967a). A Study of the Economy of Santa Clara County, California Part I. San Jose, CA: Author.

--. (1967b). Agricultural production of Santa Clara County. Info No. 218.

--. (1970). County population statistics. San Jose, CA: Author.

-.-.. (1976). Average annual employment by industry. Info, No. 578.

-.--. (1979). Average annual employment by industry. Info, No. 647.

Scott, A.J. (1982). Locational patterns and dynamics of industrial activity in the metropolis. Urban Studies, 19 111-142.

Shephard, A. (1982a, September 4). Cannery closes as irate workers rally. San Iose Mercury News, p. 1B.

-----. (1982b, November 2). Cannery's equipment, staff must find new work. San Jose Mercury, pp. 1B, 4B.

----. (1982c, December 16). Cannery workers told to take any job they can. San Jose Mercury p. 4B.

-.---. (1983, June 15). Victim, of taste, canner's cooperative files for bankruptcy. San Jose Mercury News, pp. 1B, 7B.

Sirica, J. (1982, August 22). Sealing the fate of a dying trade. San Jose Mercury pp. 1A, 3A.

---. (1982, September 8). Another cannery may pack it in. San Jose Mercury p. 1B.

S.J. cannery workers fear job loss. (1976, January 7). San Jose News, p. 26.

S.J. increases sewer fees. (1976, March 3). San Jose Mercury p. 29.

Smith, D. (1971). Industrial Location: an economic geographical analysis. New York: John Wiley and Sons.

--.--. (1979). Modelling industrial location: toward a broader view of the space economy. In F.E.I. Hamilton \& G.J.R. Linge (Eds.), Spatial Analysis, Industry and the Industrial Environment. Vol 1. (pp. 37-55). New York: John Wiley and Sons. 
-.--. (1981). Industrial Location: an economic geographical analysis (2nd ed.). New York: John Wiley and Sons.

State of California. (1980). California Statistical Abstract. Sacramento, CA: Author.

Storper, M. (1981). Toward a structural theory of industrial location. In J. Rees, G. Hewings \& H. Stafford (Eds.), Industrial Location and Regional Systems. (pp. 17-40). New York: Bergin Publishers.

Suryaraman, M. (1990, July 22). Closing of Wool cuts 400 jobs. San lose Mercury News, pp. 1E, 8E.

Townroe, P. (1969). Locational choice and the individual firm. Regional Studies, $3,15-24$.

Torriero, E.A. (1986, September 2). Swing to fresh fruit is starving canneries. San Jose Mercury News, pp. 1B, 3B.

Walker, D.F. (1975). A behavioral approach to industrial location. In L. Collins \& D. Walker (Eds.), Locational Dynamics of Manufacturing Activity. (pp. 135-58). New York: John Wiley and Sons.

Water Resources Engineers, Inc. (1968). In-Plant Treatment of Cannery Wastes. Publication \#38. Sacramento, CA: State Water Resources Control Board.

Watts, H.D. (1987). Industrial Geography. New York: John Wiley and Sons.

Weber, M. (1929). Theory and the Location of Industries. Chicago, IL: University of Chicago.

Whyte, W.H. (1958). Urban sprawl. In Editors of Fortune (Eds.), The Exploding Metropolis. (pp. 133-156). New York, NY: Doubleday and Company Inc.

Woodroof, J.G. (1988). Harvesting, handling and storing vegetables. In B. S. Luh \& J. G. Woodroof (Eds.), Commercial Vegetable Processing. (pp. 135-174). New York: Van Nostrand Reinhold.

Workers vote today on cannery pact. (1976, July 30). San Jose Mercury, p. 8. 

Zavella, P. (1987). Women's Work and Chicano Families, Cannery Workers
of the Santa Clara Valley. Ithaca, NY: Cornell University Press. 